\title{
The Time All San Francisco Fought Over School Fairness and Equality
}

\author{
Ted Fang ${ }^{1}$ \\ AsianWeek Foundation, USA
}

\begin{abstract}
Asian Americans have become a major factor in the debate over affirmative action and college/school admission policies. Yet most often their role is relegated to one side or the other of the argument - either grouped with other oppressed minorities, or else grouped with privileged white students. However, Asian Americans have their own agency and self-determination that requires attention. Beginning in the 1990s, San Francisco's Asian American community resisted mainstream hegemony and charted their own course forward. This study uses a comparative approach towards these early Asian American activists, comparing and contrasting their motivations and actions with Black activists of the time, and also with a respected federal judge, scion of one of San Francisco's wealthiest and traditional legal dynasties. News articles, notes and newsletters of Chinese American activist groups, internal school district reports, and 24 interviews are used to express how early generations of Asian Americans stood up to fight when they felt their version of the American dream was under attack, and how they focused on present-day tactical actions instead of futurelooking strategies or past historical experiences. This study also reveals practical principles that these specifically Chinese American activists employed which may have applications for all groups resisting domination and/or assimilation. The methods and tactics employed by these second-generation Asian Americans that grew up in a community remade by the 1965 Immigration Act, helps us understand how the Asian American community has developed since then, and how it is continuing to move forward.

Keywords: Affirmative action, Asian American, Chinese American, NAACP, school assignments.
\end{abstract}

February 5, 1993 was the Chinese American Democratic Club's (CADC) biggest night of the year and maybe even the biggest night ever in its 35-year history (A. Chang, 1993). Over 600 of San Francisco's top officials, community activists and business owners were greeted by traditional celebratory Lion Dancers, firecrackers, beating drums and clanging cymbals. The guests noisily feasted on an 8-course Chinese banquet, gossiping and networking between speeches from San Francisco's prominent and powerful. ${ }^{2}$ Former SF Mayor Dianne Feinstein, just elected first woman United States Senator for California and one of the hottest political celebrities of congress's 1992 Year of the Woman, was the featured speaker (Bunting, 1993).

But that night's final speech highlighting the club's top political priority came from a San Francisco newcomer, Amy Chang. Amy was young, beautiful and idealistic, "energetic,

\footnotetext{
${ }^{1}$ Corresponding Author E-Mail: teddyfang2018@gmail.com

2 Program book for dinner; "Banquet Menu: Roasted Meat Combination, Braised Seafood Soup with Shark's Fin, Pan-fried Prawns with Green Vegetable, Barbecued Peking Duck, Diced Beef with Black Pepper Sauce, Two Kinds of Vegetables with Dry Scallop Sauce, Salt-Baked Chicken, Steamed Fish" (CADC Special Events Cmte, 1993)
} 
highly charismatic, very intelligent, and a natural leader", "just a force of nature." (L. Cheng, personal communication, September 1,2019$).{ }^{3}$ CADC president Samson Wong had chosen Amy to give the closing remarks because she was a CADC rising star. (S. Wong, personal communication, January 4, 2020). ${ }^{4}$ Amy spoke passionately for Chinese families and the importance of education. She railed against institutional discrimination and "ethnic/racial limitations" placed on Chinese students. "What do you say to a child who can't get into a public school of his choice just because he is Chinese?" she pleaded to the audience. "In the political process, our children only have our voice to speak out for them," she declared (CADC Special Events Cmte, 1993, p. 1).

\section{Introduction}

Amy's speech that evening also marked the first time a line had been drawn expressing an Asian American viewpoint (specifically Chinese American) in the fight over affirmative action in education. For more than a century prior, Chinese and students labeled "Oriental" had been discriminated against in American schools (Kuo, 1998; Lum, 1975). But this time, things were different. Amy was different. She spoke out as an American citizen, and took pride in all the rights and privileges that entailed. Just the concept of an Asian American movement was nonexistent prior to her generation (Berkeley Historical Plaque Project, 2018). Unfortunately, the history of these early Asian American activists in the 1990s has not been adequately chronicled. Researchers have yet to examine the motivations and circumstances that drove their actions. Correspondingly, the literature has struggled to analyze the paradigm-shifting role of Asian Americans in educational debates.

The present study is one step towards filling this gap by following the history of the Chinese American community during this time and place. We employ a comparative analysis with other communities to show that the development of Chinese in America cannot be understood within the historical context of other racial groups, but can be better observed and appreciated when their own histories and perspectives are used as the focal point. From a policy perspective, this research highlights how the direct involvement of Asian Americans upended years of framing racial discrimination around a bipolar Black versus White dynamic. This study looks beyond the ways that portrayals and stereotypes of Asian Americans influenced the debate, and directly challenges the notion of Asian Americans as passive, "weak," or "incoherent." (Hero et al., 2006, pp. 10, 24) The present research will reveal the direct impact of Asian American organizing that forced the development and implementation of new public policies.

This paper also maps out the motivations of the Asian American community and what the American dream meant to them. This study investigates the methods and practices they employed, including: their actions to resist being integrated into public school mandates and the political/legal establishment; their tactical approach in focusing on the situation and circumstances of the present; and how they embraced serendipity and used it to their advantage. This paper closes with some observations on what this episode might foretell about the future development of the Asian American community.

\footnotetext{
${ }^{3}$ This study uses first names in repeat references for individuals, in part because some Chinese characters have the same or similar appearing surnames; additionally, the naming convention reflects the informal nature of most of the individual actors in this monograph. The exception is Judge William Orrick, Jr., who is referred to by his formal title to indicate that he most represents institutional and formal participation. In fact, not only the role he played but also the generations of his family background cause him to personify the establishment.

4 "I've always believed, if you're gonna put anyone on that stage, we're either trying to promote someone for office or promote some issue" (Wong, January 2020)
} 


\section{Literature Review}

Even to this day, many studies about race and educational reform mention Asian Americans only tangentially (Arkes \& Dent, 2020), or even not at all (Jones \& Nichols, 2020). These types of studies often subsumed Asian identity and interests to a larger good, emphasizing "a common goal" across "a broad social and political coalition" (Stone et al., 2001, p. 68). Early studies looked at how Asian Americans as a new category affected the framing of race relations (Ancheta, 1997), including how they were used as "a critical factor in the arguments" against affirmative action (Der, 1994, p. 65), and "how discourse over Asian admissions facilitated a shift" (Takagi, 1993, p. 8) "beyond a race-based analysis into one that increasingly emphasize(d) the problems of concentrated poverty" (Orfield \& Glass, 1994, p. 36).

This trend of grouping Asian Americans under larger categories diverged into two camps: One grouping included Asian Americans under the category "White, Asian or Indian" implying Asian Americans enjoy the same general advantages as their White counterparts (Black et al., 2020; Lee et al., 2020, p. 1; Nelson et al., 2017). The other studies grouped Asian Americans with other disadvantaged minorities, pointing out how "affirmative action directly benefits applicants from many Asian American ethnic groups" (Nguyen et al., 2020; Students of Sociology of Asian America, 2019 p. 8; Torres, 2020).

Interestingly, the legal field has been a major arena for discourse about Asians and affirmative action (Dong, 1995; R. Chang, 1993; Wu, 1995). Numerous articles specifically analyze the legal ramifications of the Asian American activism in San Francisco studied here (Asian American Legal Foundation, 2018; Levine, 2000, 2003; Liu, 1998). Recently, with anticipation building for the U.S. Supreme Court's ruling on Harvard's admission policies, Asian Americans have been elevated to the position of model complainants in the legal assault against affirmative action in college admissions (Students for Fair Admissions v. President \& Fellows of Harvard College, 2019; also, Arcidiacono et al., 2020; Lee, 2021).

But more and more there has been a call to document the stories and history of the Asian American community directly, as part of "a more inclusive and accurate history of all the people of America" (An, 2016; Chang, 2017; Chen \& Buell, 2018; Takaki, 2008, p. 436). The most authoritative text on school assignment policy in San Francisco from 1971 to 2005, is Rand Quinn's (2020) Class Action: Desegregation and Diversity in San Francisco Schools. Quinn includes Asian American activists playing a prominent role in events, though his approach is a generalized examination of the "complicated racial poltices" and the "relationship between 'court' and 'community' in education" (pp. 3-4). The present study's historical accounting adds another layer of depth to Quinn's work, and opens further avenues of study regarding Asian American experiences in other cities and in more recent times, including further examinations on the practices and replicability of the methodologies employed by the Asian American community.

\section{Monograph}

Amy Chang had grown up in the suburbs of San Francisco. She was high school valedictorian and went on to earn a degree in economic development from Brown University, an American Ivy League institution (Mercury News, 2018). But at Brown, Amy discovered she did not like being part of the elite. After graduation, she broke off a college romance, and spent two years in Taiwan "to study Chinese and start her work on Economic Development." But when she returned to SF, she was soon recruited into the elite again, becoming personal assistant to the Shorenstein family (at the time San Francisco's biggest real estate developer), graduating from the University of California, Hastings College of the Law, and lauded as "associate of the 
year" at one of the city's biggest law firms. But as her husband noted, Amy resisted being integrated into the legal establishment: "Honestly, she couldn't be motivated by the money component of corporate law and she dropped out of the law firm" (Yau, 2018).

What motivated Amy was that "she had dreams and talents that could help the world." (Yau, 2018). She wanted to be a lawyer to represent the underrepresented, not to make a lawyer's salary (H. Louie, personal communication, October 28, 2019). ${ }^{5}$ In San Francisco, she found community with the growing Chinese American population. She was drawn to what she saw as the unfair plight of Chinese students in San Francisco public schools. (Asimov, 1996a; Laird, 1988a; Shioya, 1995). ${ }^{6}$

\section{Table 1}

SF Public Schools Enrollment 1967-2010

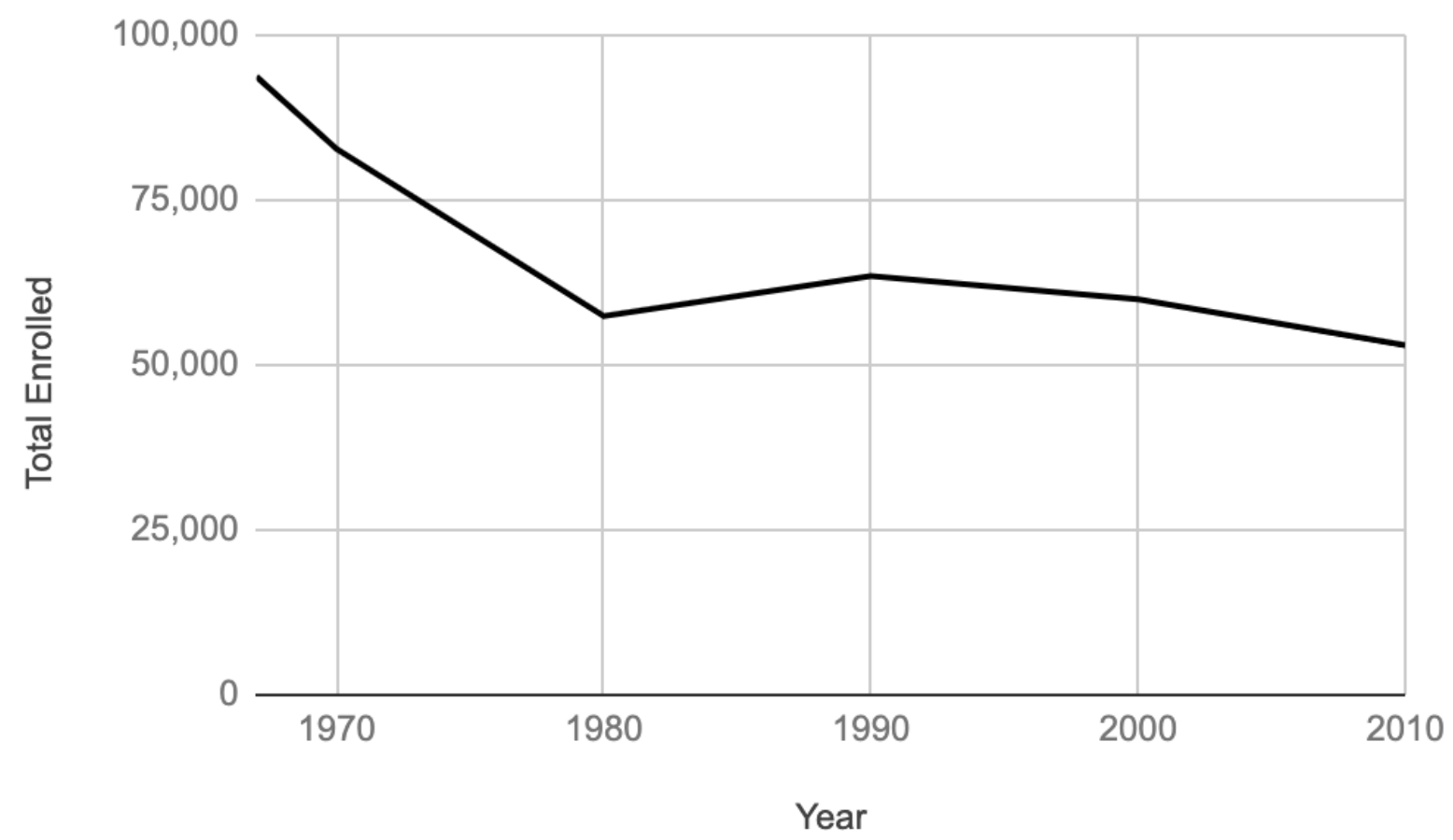

\begin{tabular}{lllllll}
\hline Year & 1967 & 1970 & 1980 & 1990 & 2000 & 2010 \\
\hline Total & 93,710 & 82,757 & 57,433 & 63,506 & 59,979 & 53,033 \\
Enrolled & & & & & & \\
\hline
\end{tabular}

Note: 43\% Decline in Student Enrollment. SF public schools declined 40,000 students between 1967-2010 with only 53,033 in 2010 (Research, Planning and Accountability Department, 2012).

Chinese had become the largest group of students enrolled in San Francisco public schools, on their way to outnumbering white students by more than two-to-one (Quinn, 2020). Yet Chinese families had almost no voice in how the schools were run (Laird, 1988b). Black

\footnotetext{
${ }^{5}$ H. Louie (2019): "Amy Chang was in many ways the spiritual leader of the CADC lawsuit. She was in her 20s. Came back to Bay Area in the late 80 s early ' 90 s. Like a lot of young people, bright-eyed, very idealistic, 'I wanna do something I wanna make a contribution and make a difference."”

${ }^{6}$ Profile of student Naomi Strom (Shioya, 1995): "I feel bad," she sighed. “It's like they should have just as much of an opportunity as I do to go to a prestigious school like Lowell. But they don't, because they're Chinese and I'm Caucasian -- and that's not fair."
} 
students' interests were strictly enforced through a 1983 federal consent decree to equalize educational opportunities between black and white students (Asimov, 1996b; Laird, 1988a). Meanwhile, the public schools superintendent position was filled by a succession of Latino males, while the SF Board of Education was dominated by a coalition known as "the three white ladies" (Fernandez \& Walsh, 1989). In fact, the only Chinese incumbent on the seven-member SF Board of Education lost his seat because he missed the deadline to file for re-election (AsianWeek, 1988)! ${ }^{7}$

Because of their large numbers in the public schools, Chinese students were shifted between schools to achieve racial balance so that no single race would dominate any of the schools (Laird, 1988a). This meant that Chinese students who needed English learning assistance were sometimes assigned to schools with no English as a Second Language (ESL) program, while students who qualified to get into the city's top academic schools were often denied admittance to make room for students of other ethnicities (A. Chang, 1993). This resulted in many unhappy Chinese parents who had nowhere to turn for help (Sing Tao Staff, 1994). Amy became their voice: "When she saw a cause - if she saw an injustice, she didn't let it go," recalled her fellow activist Lee Cheng (2019).

The injustices that Amy perceived had been decades in the making. Enacting the 1964 Civil Rights Act resulted in enforced bussing and school desegregation programs (Frum, 2000; Graubard et al., 1975) that changed the racial makeup of every school in San Francisco (SFNAACP v. SFUSD). ${ }^{8}$ The next year, the 1965 Immigration Act introduced a wave of new Asian immigrant students never before seen in San Francisco nor the nation (Pew Center, 2019). ${ }^{9}$ In one generation's time - by 1990 - Chinese students in the city nearly doubled, jumping from $13.3 \%$ to $23.7 \%$, with Asians increasing to $45 \%$ of all SF public school students (Yee, 1987). Meanwhile, the black student population stayed relatively steady at about $20 \%$. But the most dramatic about face was the $300 \%$ drop in white students from $45.3 \%$ to $14.5 \%$. The San Francisco public schools system, once dominated by white students, now had whites as one of the smaller minorities in the student body (SF Examiner Editorial Board, 1988; Quinn, 2020) Racial desegregation programs designed to address inequalities between black and white students suddenly had to deal with large Chinese populations (Greene, 1989).

But just as Chinese American student body numbers were increasing, Chinese and Asians were also increasing their involvement in San Francisco politics and policy making. The children of the Asian immigration wave begun in 1965, were going through college and starting their careers and families (Pew Center, 2019). They believed in the American values of equal representation and practiced their American right to free speech. Since the founding of the Asian American movement at UC Berkeley in 1968 (Berkeley Historical Plaque Project, 2018), the rapid increase in population of Asians and their growing influence in the 1980s was not just in SF, but also nationally, with featured articles in media like the New York Times and National Review (Linsey, 1982). The 1984 presidential nominating convention of the Democratic National Committee included an Asian Pacific Caucus for the first time (Edsall \& Johnson, 1984; McGurn \& Rothenburg, 1989). ${ }^{10}$ By 1989, the Republican National Committee had set

\footnotetext{
${ }^{7}$ From 1985 to 1999 , the SF school district was run by a succession of three male Latinos: 1985 - 1986: Carlos V. Cornejo; 1986 - 1992: Ramon C. Cortines; 1992 - 1999: Waldemar "Bill" Rojas. The "three white ladies" on the Board of Education consisted of Libby Denebeim (1981-1993), Myra Kopf (1978-1991), and Joanne Miller (19841993). The only Asian member on the Board of Education in 1988, was Ben Tom, who was elected in 1975 as the first Asian American to win citywide elective office in San Francisco. He served until 1988 when he missed the filing deadline for re-election.

${ }^{8}$ SF went from $85 \%$ racially segregated schools, to $1 \%$ (SFNAACP v. SFUSD, DF1228, 4/11/01, Declaration of Donald Barfield, Exhibit, Attachments C-5 and C-7).

${ }^{9}$ The Asian population in America grew from 980,000 in 1960 to over 23 million by 2019 (Budiman \& Ruiz, 2021) ${ }^{10}$ The convention was held in San Francisco, and Democrats nominated the first woman to be a major candidate for Vice-President, Geraldine Ferraro (Bush, 1984).
} 
up a special Asian American Affairs Office, and President George W. Bush had appointed the first Chinese woman to a cabinet level position (Chao, n.d., Fuchs, 2016). In San Francisco, Mayor Art Agnos boasted 20 Asian Americans appointed to city commissions in his first 20 months in office (Calandra \& Matier, 1989). The Chinese American Democratic Club also rose in political power" (SF Examiner, 1986). In a keynote speech to CADC, President of the Board of Supervisors John Molinari noted "The Chinese Community showed its strength and ... showed the power of (CADC's) endorsement." (CADC Special Events Cmte, 1983).

Table 2

Student Body Breakdown

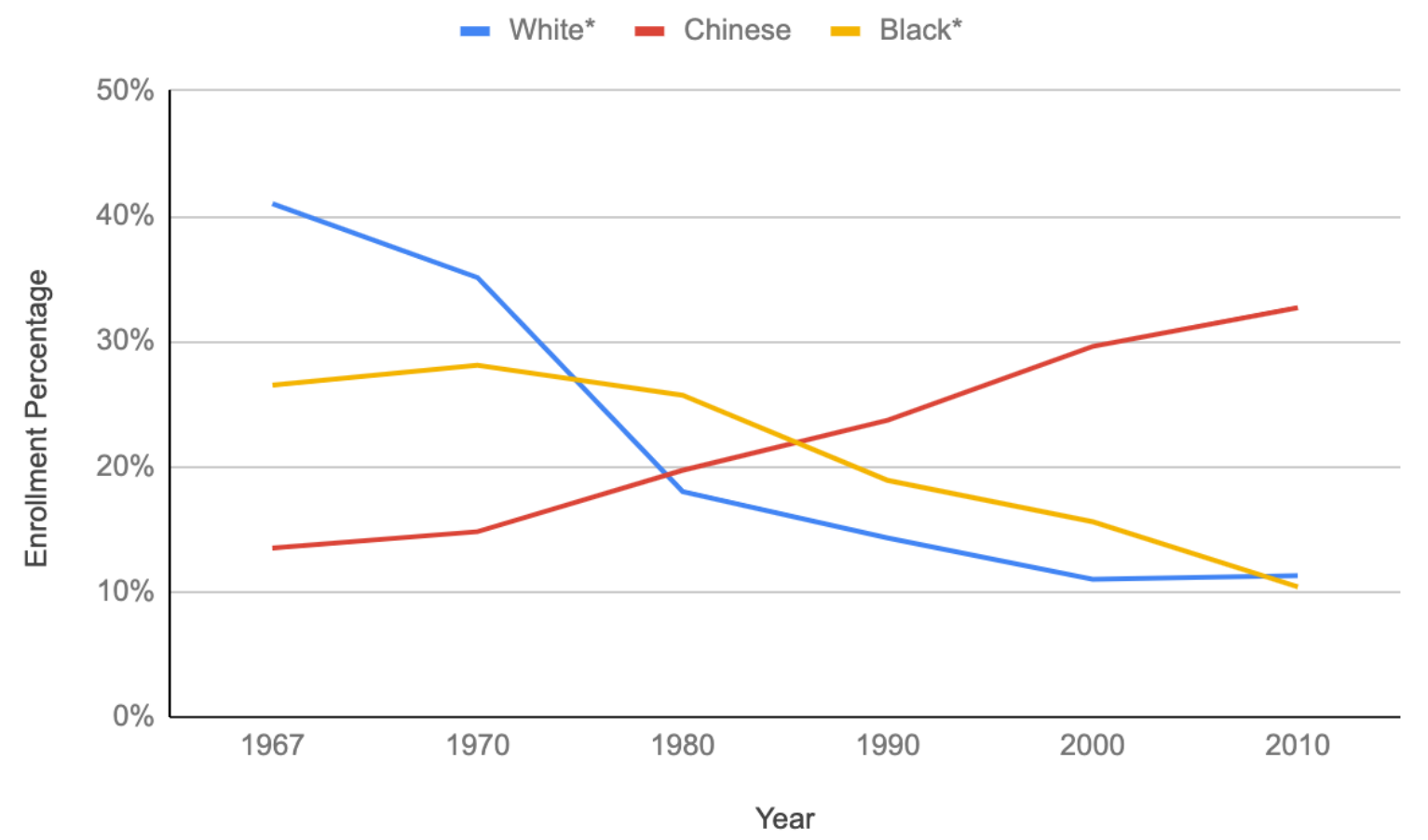

Enrollment Percentage by Demographic

\begin{tabular}{lllllll}
\hline Year & White & Chinese & Black & Latinx & $\begin{array}{l}\text { Other } \\
\text { Asian }\end{array}$ & $\begin{array}{l}\text { Native } \\
\text { American }\end{array}$ \\
\hline 1967 & $41 \%$ & $14 \%$ & $27 \%$ & $13 \%$ & $4 \%$ & $2 \%$ \\
1970 & $35 \%$ & $15 \%$ & $28 \%$ & $14 \%$ & $6 \%$ & $3 \%$ \\
1980 & $18 \%$ & $20 \%$ & $26 \%$ & $16 \%$ & $11 \%$ & $6 \%$ \\
1990 & $14 \%$ & $24 \%$ & $19 \%$ & $20 \%$ & $10 \%$ & $6 \%$ \\
2000 & $11 \%$ & $30 \%$ & $16 \%$ & $22 \%$ & $9 \%$ & $6 \%$ \\
2010 & $11 \%$ & $33 \%$ & $10 \%$ & $23 \%$ & $8 \%$ & $6 \%$ \\
\hline
\end{tabular}

Note: As listed on original survey: Black refers to African American, Latinx refers to Latino, White refers to Other White, Other Asian refers to Japanese, Korean and Filipino, Nat. American refers to American Indian (Research, Planning and Accountability Department, 2012). 
Yes, the Chinese vote could make a difference. But the reality was that none of the Chinese candidates had garnered enough votes to win. ${ }^{11}$ The inability to win elections was one of the reasons the school assignments issue became a priority. CADC's goal under 30-year-old President Samson Wong was to turn political power into electoral victories and "attain political leadership" in San Francisco. "Our aim," he wrote in his annual address "is to draw the lines that will unite this Capital City of Chinese America" referring to San Francisco. President Wong cited "innate Chinese American issues of opportunity such as small business, education and owning a home." (Wong, 1993, pp. 3-4). ${ }^{12}$

\section{Figure 1.}

Picture from a typical Chinatown banquet with up to 700 people eating and talking politics, circa 1990s to 2000s (Kee, (n.d.))

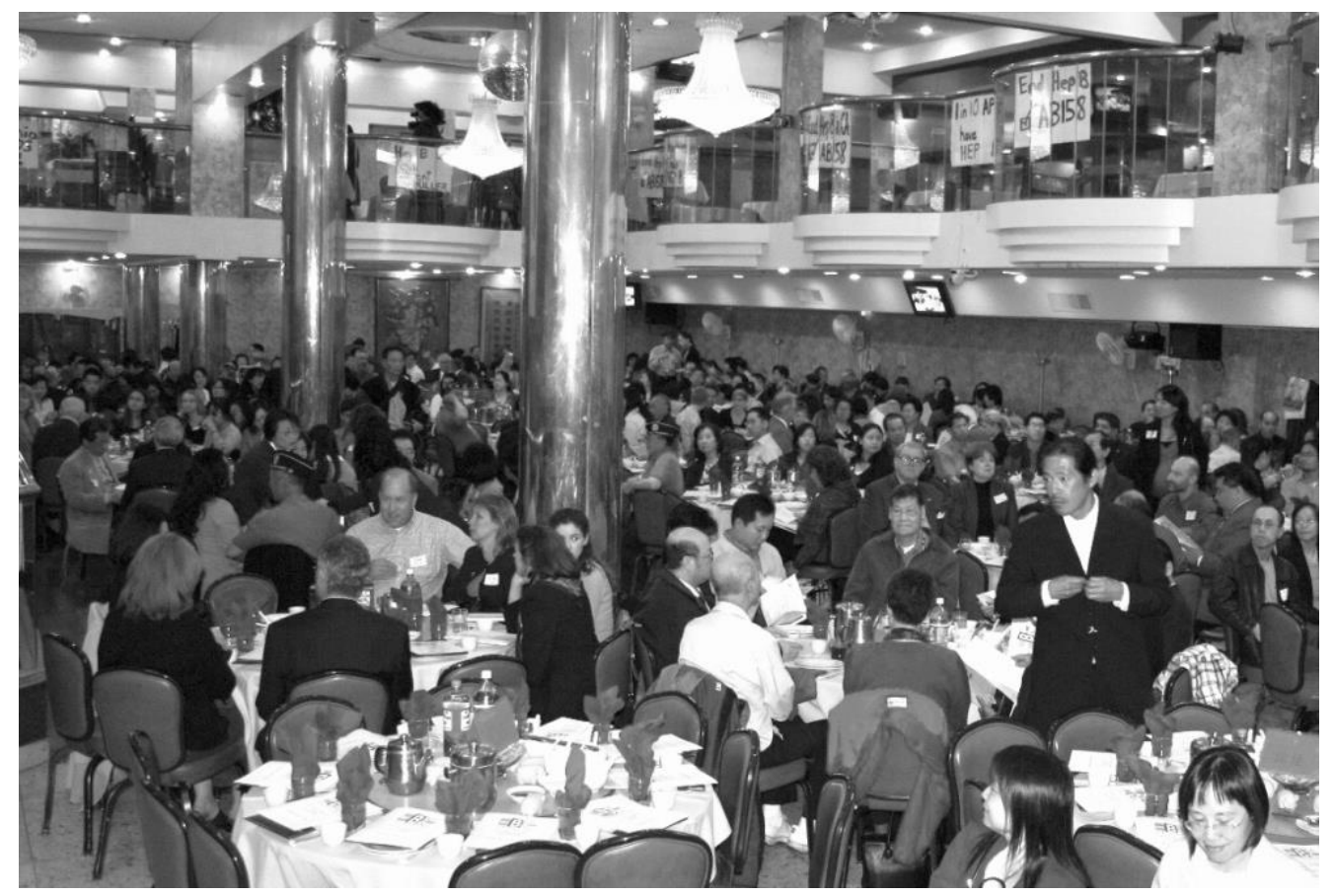

Amy herself was galvanized in part by the bitter sting of discrimination from her starcrossed college romance. He was white, from a wealthy background, and "smitten with Amy's spirit (and) kindness; her beauty and an inner toughness." He proposed and she accepted! But it was not to be. When they graduated and went to meet his family, they openly "sneered" and privately "scoffed" at Amy because of her race and class status. "How could I marry a family that despised me," she said to him as she broke off their engagement. (Yau, 2018). Amy did not want to be integrated into that kind of society. She left and spent the next two years in Taiwan searching for her identity. When she returned to San Francisco, she had a new sense of self and wanted to make a positive impact for Chinese in America. Her initial approach was "you really need to get voter representation." She started registering voters with the non-partisan Chinese

\footnotetext{
${ }^{11}$ By 1977, Chinese American Gordon Lau had won a district supervisor seat but lost it in 1979. Tom Hsieh was appointed in 1986 but won in his own right a citywide seat in 1988. Six years later, the third Chinese American and first Asian American woman - Mabel Teng - won election citywide.

12 Samson was keenly aware of the division among Chinese activists as he was elected to lead CADC that year by a margin of only three votes. "It was always in the back of my mind that I became (CADC) president by a very narrow margin," so Wong recalled his goal was "trying to achieve consensus in the club, bringing everyone together behind certain issues." (Wong, January 2020)
} 
American Voters Education Committee (CAVEC). But as she stood behind her ironing board on street corners with her voter forms and CAVEC outreach fliers, "she started running across these parents" who were mostly blue collar, most of them Cantonese speaking with limited English abilities. Amy "spoke broken English with them" about the troubles their families faced with SF public schools (H. Chow, personal communication, March 16, 2020).

"There were two sets of parents," Amy's husband Dr. Harrison Chow recalls (March 16, 2020). The first set "couldn't get their kids into their neighborhood schools". That was a big deal "because it limited their kids' ability to just walk to school. . . . Having a parent to bring them to school was a hardship issue." The other set of parents had children who were not allowed to attend Lowell High School, San Francisco's top academic school and one of the highest-ranked in the nation. "The Lowell thing was difficult because it was their meal ticket. Once the kid went to Lowell, then the kid was going to go to UC Berkeley" or another topranked university, on their way to a stable, salaried professional career. For these families, getting their children into Lowell "was their ticket to the American Dream" (Chow, March 16, 2020).

The problems for these Chinese families stemmed from the contradiction between changing demographics and a 1983 desegregation consent decree ordered by the courts. The Asian population was not only increasing generally, Asians were also concentrating themselves in certain neighborhoods. This concentration was even higher in the classroom because many white families took their children out of the public schools system. When the number of Chinese students hit the consent decree quota of no more than $40 \%$ (for example at schools teaching English as a Second Language), many Chinese students were reassigned and denied entry to their school of choice. For Lowell High School, it was a matter of academics and meritocracy. Entry to Lowell was determined by a set criterion of academic markers. Too many Chinese students met or exceeded these academic benchmarks. Their numbers began surpassing the $40 \%$ quota cap in 1986 (Curtis, 1986). ${ }^{13}$ The following year, a limit was set on the number of Chinese students admitted to Lowell. Accordingly, the academic criteria were raised for Chinese students, forcing Chinese to score higher solely based on their race (Levine, 2000).

Amy was shocked that these racial caps on Chinese students were mandated by a courtapproved desegregation consent decree (Cheng, 2019). She looked for a political solution. Through Henry Louie, chairperson of CAVEC, Amy was introduced to the CADC political network. CAVEC served as the non-partisan voter registration arm of the Chinese American Democratic Club. ${ }^{14}$ Henry was an early mentor to Amy, but soon he and other CADC members like Roland Quan, Louis Hop Lee, Victor Seeto and BQ Seeto began rallying around Amy's charismatic leadership (V. Seeto, personal communication, September 19, 2019). Louis (personal communication, March 20,2020) recalls that Amy pored over all the materials put out by the school district and the legal briefs regarding the school assignments consent decree: "it was a good symbiotic relationship because ... she knew the technicals of it but she didn't know the politics of it."

Amy, Louis, and the others "made a checklist of all the elected officials, the (Board of) Supervisors and all the people on the Board of Education" (L. Lee, 2020). They held meeting after meeting, after work, at each other's homes. They even organized community demonstrations in front of the Board of Education. One time, CADC organized a group of Chinese parents to come wearing painter's caps which they theatrically took off in unison to

\footnotetext{
${ }^{13}$ As of April 1986: 43 percent of Lowell's students were Chinese, 24 percent white, 8 percent Filipino, 7 percent Hispanic, 6 percent black, 3 percent Korean, 3 percent Japanese, and 5 percent other (Curtis, 1986)

${ }^{14}$ Henry Louie was a longtime city health inspector recruited to be part of CADC to help represent the interests of civil service city employees. He was on the board of CADC and was elected CADC president after Samson Wong. (D. Chan, 2020)
} 
the chant "Off with the Caps" referring to the racial caps limiting Chinese students (D. Chan, personal communication, November 20, 2019).

But all of their efforts were to no avail. For reasons they could not understand and would not accept, the CADC activists "got the door shut in (their) face by everybody. Nobody was willing to support" them (L. Lee, 2020). The reality was that since the U.S. Supreme Court ruled against school segregation of black students in the 1950's, a far-reaching infrastructure and culture had established itself to desegregate public schools. Nearly two hundred school consent decrees were created and implemented throughout the nation, just like the one in San Francisco (Civil Rights Division, Dept. of Justice, 2021; Parker, 2000). "We were thinking that politically they would make the compromises," recalls Louis Hop Lee (2020), "but they weren't about to, because the politics were too strong for the status quo."

\section{Table 3}

Chinese-Attended Schools Impacted 50\% Higher

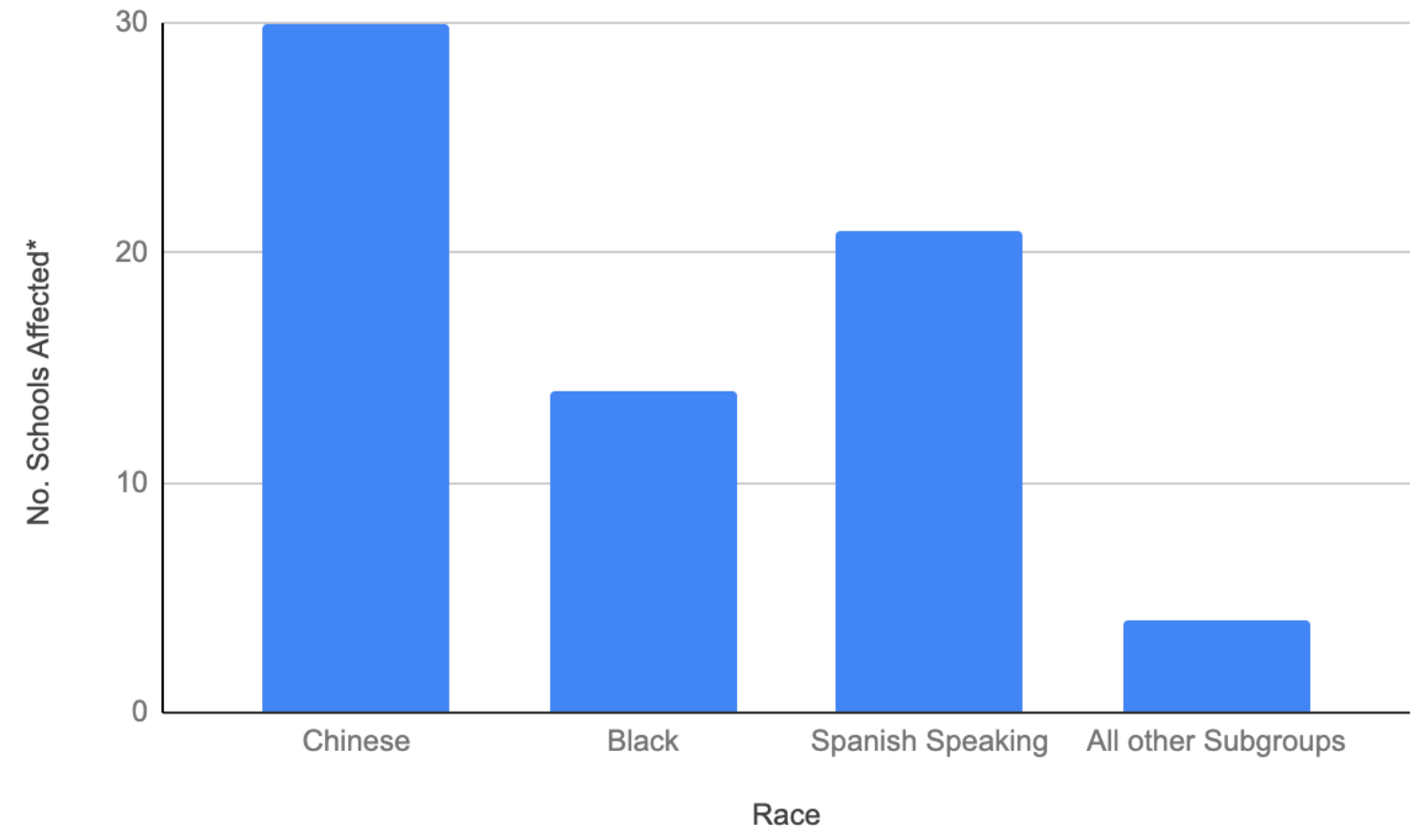

\begin{tabular}{llll}
\hline Race & $\begin{array}{l}\text { No. Schools } \\
\text { Affected* }\end{array}$ & $\begin{array}{l}\text { Percent of Total } \\
\text { Schools }\end{array}$ & $\begin{array}{l}\text { Percent Impacted } \\
\text { Schools }\end{array}$ \\
\hline Chinese & 30 & $28 \%$ & $44 \%$ \\
Black & 14 & $13 \%$ & $20 \%$ \\
Spanish Speaking & 21 & $19 \%$ & $31 \%$ \\
All Other Subgroups & 4 & $4 \%$ & $5 \%$ \\
Total & 69 & $64 \%$ & $100 \%$ \\
\hline
\end{tabular}

Note: Racial caps limit Chinese at almost half of all 69 schools. Source: (Quinn, 2020, Table 15). Original Source is in Declaration by Amado Cabezas on behalf of Chinese American Democratic Club. Cabezas obtained data from SFUSD Planning and Research Department.

In truth, there was also what former CADC president Doug Chan delicately referred to as "an ideological inconsistency" in the CADC activists' assault on affirmative action quotas (2019). Henry Der, long time Executive Director of Chinese for Affirmative Action (CAA), a 
leading community civil rights group, was a vocal opponent of the efforts by the Chinese parents. He correctly pointed out that many in the Asian community were benefiting from and taking advantage of affirmative action programs. In particular, Asian-owned businesses like many run by CADC members, often received government and corporate contracts in part based on quotas and set-asides for minority businesses. "How can you call for just a merit-based system (for Lowell High School) while you are calling for affirmative action in contracting?" Der asked (personal communication, December 6, 2019). "You aren't being consistent. You can't have it both ways." 15

In a way, Der was putting it mildly. Many outsides of the community felt Asians had little to complain about, and indeed were some of the main beneficiaries of the consent decree system. At Lowell for example (the city's highest-achieving high school), nearly two-thirds of the student body was Asian - with Chinese at almost half (Cabading, 1983; Curtis, 1986). Moreover, Chinese were "the largest group at most of the best schools in the city" (Walsh, 1993); they were assigned their school of choice more than any other group; and they were the least likely to be bussed out of their neighborhood to attend school (Lim, 1994). In fact, San Francisco had even created "the only elementary school program in the United States in which all subjects" were taught in Cantonese and in which students were almost exclusively Chinese (Walsh, 1989). Lulann McGriff, President of the San Francisco chapter of NAACP, took Der's words a step further regarding Chinese families: "They can't have it all. That's what the consent decree says: No group can have it all" (Walsh, 1993).

The San Francisco NAACP first sued the San Francisco school system in 1969 because white students dominated all the best performing SF public schools (Johnson vs. SFUSD, 1971). There were hardly any Asian or Latino children, but black and white students were starkly segregated by race and by quality of education (Quinn, 2020; Research, Planning and Accountability Department [RPA], 2012) ${ }^{16}$ In 1969, 80\% of black children were concentrated into 27 schools. Twenty-one schools had a $71 \%$ black student body, going as high as $96 \%$ (Johnson vs. SFUSD, 1971). The segregated schools were consistently the lowest in educational achievement. Stanford University researchers explicitly linked improving "achievement of Negro students" to "increasing the degree of integration" in schools (Johnson v. San Francisco Unified School District, 1971, 339 F. Supp. 1331; Platt \& Harker, 1967, pp. 3-4).

In response to NAACP's lawsuit, the U.S. Federal Court in 1971 ordered the SF Unified School District (SFUSD) to implement desegregation programs to ensure that neither black nor white students would make up a majority at any school (Johnson vs. SFUSD, 1971). Busing programs enforced desegregation by driving some kids across town to schools that would otherwise be dominated by one race (SF Examiner Editorial Board, 1970; Wood, 1970). By 1978, the SF School district was looking to modify the 1971 Court Order, reduce costs and cut back on desegregation programs (Levine, 2000; Quinn, 2020). ${ }^{17}$ The NAACP strenuously objected and brought a second lawsuit (SFNAACP v. SFUSD, 1979). ${ }^{18}$

That same year of 1978, Lulann McGriff started working as Assistant Regional Director for the Western Region of the NAACP where she had just completed an internship for her master's degree program in social work (P. Cohn, personal communication, November 12,

\footnotetext{
${ }^{15}$ Henry Der went on to serve as California Department of Education Deputy Superintendent for Instruction (19962001), and superintendent of the Emeryville school district (2001-2004) (May, 2012).

${ }^{16}$ SFUSD (RPA, 2012) student body demographics in 1969: 13.1\% Latino, 39.9\% White, $27.1 \%$ Black, $13.6 \%$ Chinese, $1.8 \%$ Japanese, $0.1 \%$ Korean, $0.2 \%$ American Indian, 2.6\% Filipino

${ }^{17}$ The Johnson case was vacated by the U.S. Ninth Circuit Court of Appeals 500F.2d 349 (9th Cir 1974)

18 In the 1978 lawsuit, the NAACP added the State of California as a defendant and funder for educational programs, and also petitioned for class representation in desegregating schools and improving education to encompass all students of SF public schools, including white students and Chinese students. (Levine, 2000, p. 43; Quinn, 2020, pp. 88, 89)
} 
2019). ${ }^{19}$ She was in the room when local and national NAACP attorneys had their SF meetings to strategize and craft their filing of the second desegregation lawsuit. As factual discovery and legal maneuvering in the case extended through 1983, Lulann went on to work in City College of San Francisco's counseling department. In her day job she experienced first-hand, issues of racial inequality in the educational system. After hours, she would go to NAACP's offices as a volunteer (Cohn, November 2019) and help devise a comprehensive citywide schools desegregation program that would eventually be instituted in the 1983 consent decree ordered and supervised by newly assigned U.S. District Judge William Orrick, Jr. (Quinn, 2020). Lulann thrived in the high-energy NAACP environment (E. McGriff, personal communication, June $27,2020) .{ }^{20}$ By 1986 Lulann would become president of NAACP-SF, and the only person ever to serve four consecutive terms in that position. She also was elevated to serve as Director of the Western Regional Office of NAACP (P. Cohn, personal communication, May 1, 2020).

Lulann came to be known as "the mother" of San Francisco's school desegregation consent decree, and the decree's "watchdog" and "guardian", until her early passing in 1998 at age 55 (Asimov, 1996b; also, Dougan, 1998). In retrospect, it seemed Lulann's whole life was preparing for this role. She was always proud to call herself a native San Franciscan, although her father actually brought their family to live here when Lulann was 3 days old. That was in 1943, the middle of World War II (I. McGriff, personal communication, May 23, 2020). Lulann's family was part of the huge wave of 40,000 Black Americans that moved to San Francisco, proudly working for America's wartime efforts building a fleet of ships at Hunters Point Naval Shipyard and other duties (Broussard, 1993; Carlsson 1994). Lulann's parents went about integrating their family into San Francisco society. ${ }^{21}$ Lulann's family went to church and socialized in the Fillmore district where the whole neighborhood knew the McGriff family (I. McGriff, 2020). The Fillmore then was the "downtown for black people" (I. McGriff, 2020), also known as the "Harlem of the West" and filled with successful black storefronts, theatres and of course upscale jazz nightclubs featuring performances from the likes of Billie Holiday, Duke Ellington, Count Bassie and Etta James (Pepin \& Watts, 2006, p. 1).

It was in this "serious middle class" environment that Lulann was raised, becoming an "ambitious", "self-driven person", expecting to have, and working "to get a better life" (I. McGriff, 2020). Though her parents were not professionals, that was who she grew up around. Lulann's second daughter, Ilona, describes her family's friends and acquaintances as "Jack's and Jiller's" (I. McGriff, 2020), referring to the group Jack and Jill of America, described by the New York Times as "the venerable social club for children of the black middle class, who get together for ski trips, cotillions and volunteer work" (Rohrlich, 1998). This national invitation-only membership association was begun during the 1930s Great Depression by black mothers looking "to find and create enriching activities for their children", because then most middle-class activities were segregated for white families only (Wells, 2016; also, Thompson 1978).

Much of Lulann's adult life was centered around the correcting of past injustices, and the integration of black people into white mainstream society. The Jim Crow racial caste system of anti-black policies that segregated blacks from whites in the South only took on an "outward gentility" in San Francisco - "not 'Jim Crow', but 'James Crow" (Fulbright, 2009; Richardson, 1999). For example, Lulann's father, who "was very classy and refined" and was "always very

\footnotetext{
${ }^{19}$ Another example of the support network that Lulann was plugged into: Peter Cohn was teaching at SF State University when she went back to school to earn her Masters in Social Work. He recommended the NAACP internship to fulfill Lulann's practicum.

${ }^{20}$ Lulann was "industrious", "self-propelled", and "enlivened from work versus depleted from it."

${ }^{21}$ Lulann's family lived on Margaret Avenue in the Lakeview Ingleside neighborhood, "a significant street for African Americans ... where most of the doctors, and the teachers and the lawyers lived all in that one block of Margaret" (I. McGriff, 2020).
} 
well dressed", liked to have "a nice car." But when he wanted to get a fair price on buying a new one, he had to ask one of his white friends to buy the car for him and he would make the payments to his friend (I. McGriff, 2020). ${ }^{22}$

\section{Figure 2a}

Blocks from where Lulann's family lived, Cecil Poole (assist. DA) and his wife stand on the front lawn of their house. Someone left a burning cross on their property. 1958, when Lulan was 15 years old (Downey, 1958).

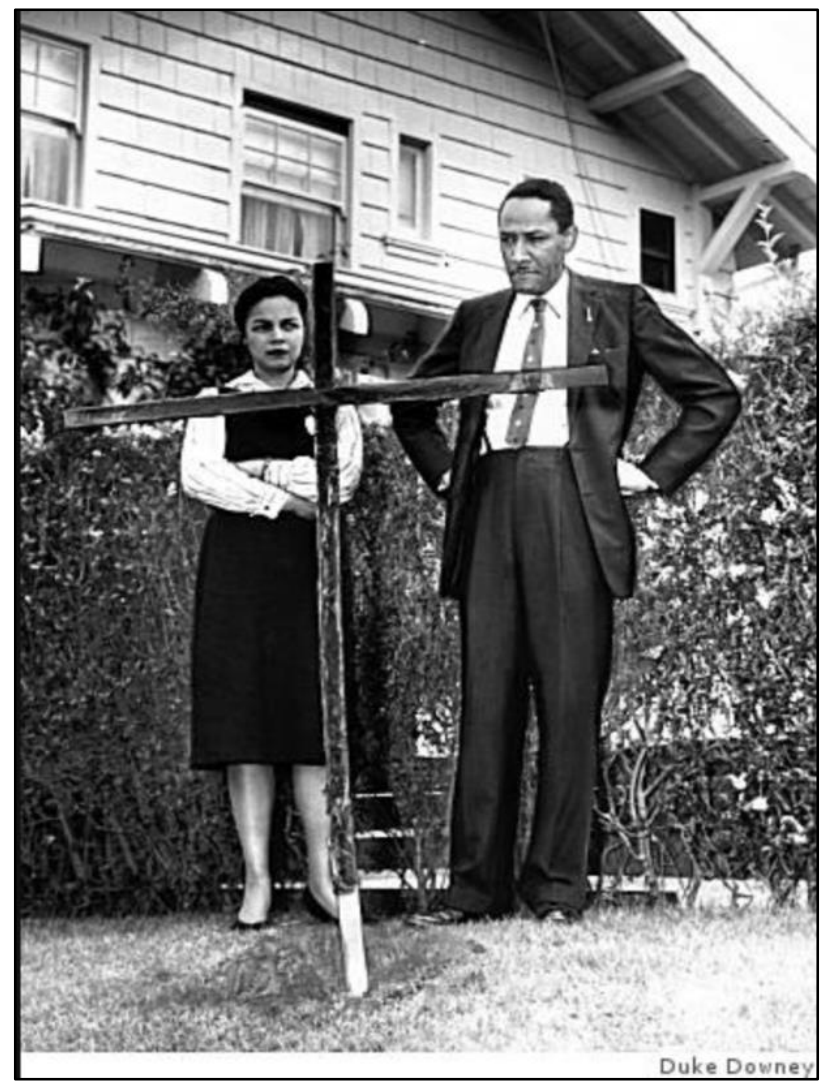

\section{Figure 2b}

Juilanne Malveaux, Luann S McGriff, and Peter Cohn, San Francisco, California (Gatson, 1985).

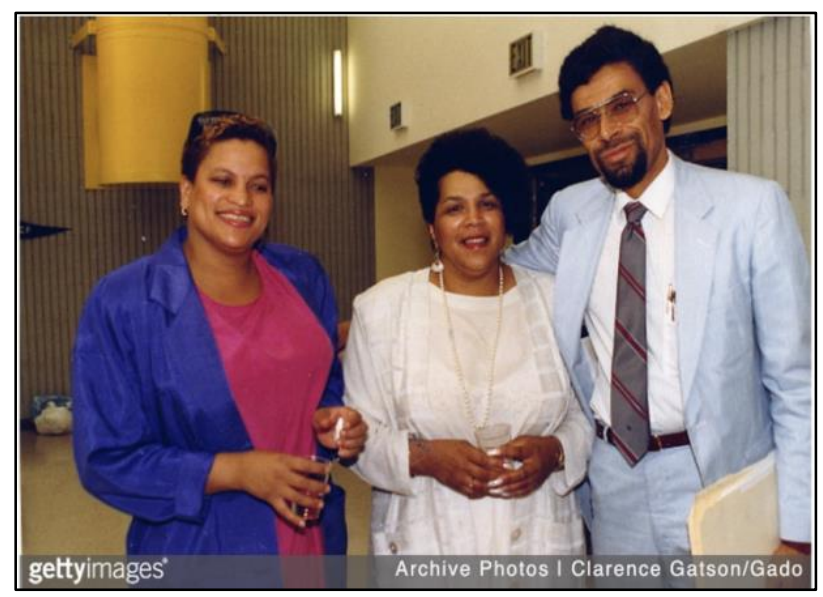

\footnotetext{
${ }^{22}$ The car dealers were still located on Van Ness Avenue's auto row. By this time, it was certainly illegal to not
} sell cars to Blacks, but often at a much higher price and under less favorable terms (Richardson, 1999). 
At the time Lulann joined NAACP, San Francisco's school desegregation plan was at a crossroads. So was Lulann's life path. Since the 1971 lawsuit, desegregation efforts had accomplished much. The number of segregated schools in San Francisco had dropped from over $80 \%$ to less than $30 \%$. But then faced with budget cuts, the school district proposed modifying school integration programs. NAACP-SF faced internal divisions about how to proceed: should their focus be holding on to hard-fought gains, or should they gear up for another difficult court battle to further desegregate all public schools? (Quinn, 2020) Lulann's goals were clear: She wanted to ensure that "African American students not only got their education in general, but that they were performing at a high level". She wanted to implement a "holistic" approach towards education that improved "the way students were treated" and raised "expectations for what African Americans could accomplish" (E. McGriff, 2020).

The NAACP team met at their Western Regional offices located in downtown San Francisco's landmark Flood Building. Verna Canson was then regional President, and the lawsuit was "coordinated through the national office," bringing in attorneys Nathaniel Jones of Ohio, who was NAACP General Counsel and soon to be appointed U.S. Appellate Court Judge, and Thomas Atkins, former Boston City Councilman and NAACP's chief desegregation counsel nationally. Locally, Peter Graham Cohen represented SF NAACP and would continue to serve as counsel for the SF NAACP and the public-school children of San Francisco for the next 25 years. Establishment SF law firm McCutchen Doyle Brown \&

Enersen, and also Eva Patterson, of the Lawyers Committee for Civil Rights rounded out the co-counsel. It was this network of "collective thinking ... from the very beginning" which characterized the support that galvanized to desegregate San Francisco schools (Cohn, November 2019).

But the second lawsuit brought by NAACP in 1978 never went to trial either. Four years later, the suit dragged on, and begrudgingly even the school district's attorneys realized the schools would need to be completely desegregated. But the sides could not agree on how to do it. Judge Orrick set a hard deadline for the end of the year and, at the proverbial last minute, on December 30,1982, the parties agreed on a settlement that would be enforced by the federal government. Through this "consent decree", the court ordered that no school in San Francisco would have any one racial or ethnic group comprising more than 40-45 percent of the student body. Just as importantly, special programs would be put in place to achieve educational parity for all students. The consent decree was more far-reaching than anything before and involved all levels of government: local schools were being integrated, state government provided funding for educational programs, and the federal courts monitored implementation. It was also effective: ten years after implementation less than one percent of schools remained segregated in San Francisco (Quinn, 2020).

That was in 1993, the same year Amy and the Chinese families zeroed in on the consent decree's racial quotas as the source of their problems. They had no clue about any of this history, struggle or background. They only knew that their families came pursuing the American dream, and they were enjoying their family's and their own progress. The issue for them was that they never thought "they would hit ceilings", as Michael Chan put it, another former CADC president. Asians had been encouraged by society to learn English and pursue their academic achievements in the ' 80 s (M. Chan, personal communication, April 28, 2020). But at the same time, top academic universities from University of California, Berkeley to Harvard University, and even top high schools like Lowell High, began to put caps on enrollment and requirements limiting Asian students (Takagi, 1990, p. 587). Meanwhile, more than 12,000 students were not allowed to attend San Francisco schools with English as a Second Language programs (Lau, 1993). These quotas made Chinese American families feel targeted and discriminated against because of their race, contrary to their belief that they had a right as Americans to be treated fairly. 
This was quite a different perspective from the Black community view that saw those American rights as hard-fought victories from decades of struggle. As Michael Chan (2020) explained: During the 1950s and 60s, from the nonviolent movement to the urban riots that "amplified" their message, "it was like the Black community was burning the candle at both ends". Michael was also a protege of Harold Yee and 15-year executive director of one of the largest nonprofits in California to support minority businesses, ASIAN, Inc (ASIAN, Inc., 2020). African Americans saw "their role as being the heavy lifters" in achieving racial equity programs like affirmative action. They struggled and suffered in order to achieve fairness in education for communities of color, which the Chinese families now took for granted. And African American activists had also worked hard to unravel engrained discriminatory practices and to institutionalize desegregation programs, which the Chinese parents now sought to overturn (M. Chan, 2020).

But as Samson Wong had noted earlier, the Chinese were no monolith in ideology. Many Asian activists who had come of age during the civil rights movement felt that attacking the consent decree could harm larger, and longer-term goals. California Superior Court Judges Lillian Sing and Julie Tang were like that. Judge Sing became the first Asian American woman judge in California in 1981 (Superior Court of San Francisco, 2015). Judge Tang was the first Asian American woman to run a major citywide supervisorial campaign in 1986. Lillian was a co-founder of CAA and a past president of CADC (Superior Court of San Francisco, 2015). Julie was the first employee at CAA and groomed by CADC to run for office (L. Sing \& J. Tang, personal communication, February 18, 2020). They knew all sides of the community. They were sympathetic to Amy's group and many at CADC for "truly looking at what is good for the Chinese community" in terms of their children's education. However, both judges shared the concern that the fight against the consent decree was "not taking into consideration other communities' interests." "We believed in coalition politics," says Lillian, "We believed we were riding the coattails of African Americans. In terms of bussing, education, we should not step on those who benefited (from those programs). We had to work together" (Sing \& Tang, 2020).

Yet the judges also experienced how established liberal political groups treated Chinese in politics as newcomers and did not treat them fairly in San Francisco coalition politics. When Julie Tang ran for the Board of Supervisors, she earned the endorsement of the major African American Democratic political clubs and even the San Francisco Democratic Party. But when it came time to publicize the endorsements, those groups left Tang off their campaign materials! "There was a conspiracy among the Democratic establishment", says Tang. It was just another example of San Francisco's rough and tumble 1980s, and the Chinese community getting "burned" by more established players. So, from these interactions, both judges also understood why many Chinese activists like those in CADC felt the need "to solidify" their own interests "first, before taking care of everybody else's" (Sing \& Tang, 2020).

Although Amy turned to the old-timers at CADC for political guidance, it was her fellow youngbloods who injected energy and momentum into her efforts. Amy had become dejected after hitting so many stone walls, but came home one summer in 1993 excited to tell her husband: "I just met this kid. He's just so full of energy. His name is Lee Cheng, and he's ready to fight. And I can't believe I just met this other kid named Alan Tse. He's just ready to go punch somebody (over this issue)" (H. Chow, personal communication, March 20, 2020). Both Lee and Alan had just graduated college. Like Amy they were taking time off to decide their next step in life, and evaluate what was worthwhile to them (Cheng, 2019). Unlike her, they were "immature and hot-headed" compared to Amy who was 10-years their elder, had already earned her graduate degree and had traveled the world. She ended up taking them under her wing, acting as "mother-hen revolutionary" of their group. Amy "was our leader.... She was the glue and she was the accelerant.... She provided the encouragement and inspiration," recalled Lee Cheng (2019). After working together on this issue, they all decided to become 
lawyers. ${ }^{23}$ For the rest of their lives, Amy became "like a big sister to them" (Chow, March 20, 2020).

The group began to solicit lawyers and convened a meeting with virtually all the large law firms in San Francisco. But even with commercial attorneys, they faced rejection. The gathered attorneys "all nodded appreciatively, and they said: 'Oh, so sorry, we can't take this (case). Sorry, not my cup of tea," recalled Lee (2019). "They gave us some legal argument why our lawsuit would not be successful: ... 'equality is the law of the land', 'integration is the law of the land," 'Victor Seeto (2019) recalled. "Most of them said 'This is politically unpopular', plus 'We don't want to take on NAACP'”, observed Henry Louie (2019).

At a seeming dead end, Amy sought out her group of young friends once again. Tony Lee was a recent graduate from Harvard Law School and a new associate at a law firm specializing in class action suits. When the partner he worked with at the Lieff Cabraser law firm began casually chatting about college admission controversies, Tony brought up conversations he'd had with Amy. "I said (to partner Dan Girard): 'Well you know there's something similar going on in the San Francisco school district.' He said 'really?" ' recalls Tony (personal communication, March 27, 2020), "That's when we decided to (be part of) the lawsuit." ${ }^{24}$ Girard and Lee were soon joined by UC Hastings constitutional law professor David Levine. Levine had heard about the case from fellow Hastings faculty who had children enrolled at Lowell High School (Levine, 2000). ${ }^{25}$

The Chinese parents' first foray into the legal arena was a few months earlier, in 1993. CADC had changed the name of its Education Committee to become the Consent Decree Task Force with Amy serving as chairperson (CADC, March 1993a). That April, Louis Hop Lee made an Amicus filing with the federal court regarding the consent decree and was invited to speak at a "fairness hearing" before Judge Orrick (CADC, May 1993b; SFNAACP, DF 750, April 22, 1993). ${ }^{26}$ The hearing was to assess the consent decree at its 10 year mark of implementation and was the culmination of an eight-month long process to approve a lengthy report authored by a nationally-renown panel of experts (Asimov, 1992). Louis was one of only a few parties invited to speak at the hearing (Wong, 1994). It was the first time the Chinese parents would have their viewpoints presented to the judge who had set the school assignments system back in 1982 .

The presentation was not well received. "He reacted visibly," recalls Louis (2020). "He didn't like what he was hearing at all." Louis used stark language with the judge to depict the consent decree as wielding "state powers" to discriminate against Chinese students. Why continue the consent decree when it "hurts some people without helping others?", Louis questioned. In fact, the panel of experts in 1992 had concluded that implementation of the consent decree did not help improve academic achievement of poor performing students. There was a divergence in effectiveness. "San Francisco schools (had) achieved integration," the SF Chronicle explained, but they had also "failed to help thousands of Black and Latino children" to improve their education (Asimov, 1992). Judge Orrick, along with the consent decree's two parties, SF NAACP and the SF Unified School District, did not consider dismantling the consent decree (Levine, 2000). Orrick noted the effectiveness in desegregating the schools, and ordered the racial quota-limits to be maintained. Meanwhile new educational programs were proposed to improve the quality of education (SFNAACP, 1992).

\footnotetext{
${ }^{23}$ Amy went to UC Hastings Law School, Lee went to UC Berkeley, Boalt Law School, Alen Tse went to Harvard Law School.

${ }^{24}$ But it was still not smooth sailing. The other partners "did not want the case" because of "the political ramifications." Eventually, Dan Girard left the firm for additional reasons, but took the case with him. (T. Lee, 2020)

25 "(A)s a matter of principle, he (Dan Girard) gave up a lot of money to do this case" (Levine, March 2020)

${ }^{26}$ Co-authored by Juliet Gee and Amado Cabezas
} 
In his rulings, Orrick continued on the path that he had set more than a quarter century before. He was the third judge to be randomly assigned the consent decree case in 1979 - the first two judges both recused themselves for different reasons (Quinn, 2020). Orrick took on the case in earnest and eventually saw it as one of the most important cases of his career (Orrick, 1989). He had joined the federal bench just five years before and had no experience with school desegregation cases (Orrick, 1989). But he did have first-hand experience in wielding the power of the law, and he had a supreme confidence in his mastery of utilizing the law as a power to "effectuate resolutions" and do good (Cohn, 2020).

Judge Orrick was scion to one of San Francisco's most prominent legal dynasties. ${ }^{27}$ His father started the family-named law firm that would grow to become the 35th largest law firm in America by 2020, with over \$1.1 billion in revenue and more than 1,000 lawyers in the firm (Law.com, n.d.). Judge Orrick took to the family calling, graduating from Yale University and UC Berkeley's Boalt Hall School of Law. Through connections, he was even able to interview the Chief Justice of the U.S. Supreme Court for his college newspaper. After law school, he was recruited to be part of President John F. Kennedy's Justice Department in the early 1960s (Orrick, 1989). ${ }^{28} \mathrm{He}$ was one of a "group of young lawyers who were seen as smart fighters for justice" working under the leadership of Attorney General Bobby Kennedy (D. Campos, personal communication, April 2020). He was active in the Civil Rights Movement, volunteering to go to Montgomery Alabama to protect the Freedom Riders from attack during the unrest over desegregating public facilities. Later he led the Department of Justice's Antitrust division, where he became the nation's most aggressive monopoly-buster breaking up big corporations (Orrick, 1989).

Orrick's time in the Kennedy administration were his most flamboyant and activist years. He was greatly inspired by President Kennedy's Camelot and enthusiastically moved to Washington DC "to help move the world at least a quarter of an inch off its axis and make things better" (Orrick, 1989, p. 137). He worked "night and day, and Saturdays and Sundays to do anything" the President wanted to have done (p. 137). He relished the power and responsibilities in Washington for "running the government", and for being an Assistant U.S. Attorney General (p. 219). "I had the greatest client in the world, the United States," Orrick later recalled. "Justice was always on our side, at least so I thought" (p. 150).

In 1974, as part of a political deal with Democrats, Republican President Richard Nixon appointed Orrick to the U.S. District Court. ${ }^{29}$ Judge Orrick found his true home on the federal bench. "I love the law," he would say, "and the law without clients is a particularly good way to live" (Orrick, 1989, p. 245). He gained a quick reputation for his stern demeanor and being a "stickler on decorum and proper behavior by lawyers" (p. 279). He saw his duty as creating and maintaining "order" in the courtroom so that "reasoned arguments" by opposing attorneys would allow "the light of justice to prevail" (p. 280). His experience in Washington opened his eyes to the power of the federal judiciary too. He saw the U.S. government as a "three-layer power structure set forth in the constitution." He considered the federal judiciary to be "the

\footnotetext{
${ }^{27}$ In addition to his father founding the Orrick law firm, Orrick Jr.'s son, William Orrick III carried on the legal dynasty for a third generation. Orrick III was noted for being rebellious and not joining the Orrick firm, but actually he mostly followed his father's footsteps: appointed to the federal bench by President Barack Obama in 2013; prior to that Orrick III was Deputy Assistant Attorney General in the Civil Division of the United States Department of Justice; prior to that he had graduated from Yale University as well.

Orrick Jr's brother, Andrew Downey Orrick was a prominent Republican and served as acting chairman of the U.S. Securities and Exchange Commission in San Francisco under President Dwight Eisenhower in the 1950s.

${ }^{28}$ Even when the Orrick law firm had just started, Judge Orrick's mother who "didn't know a great deal about the practice of the law" and spent her time organizing "one, if not two, bridge clubs", did know that her family's law firm "was a very good firm and a high-class firm" (Orrick, 1989, p. 8)

${ }^{29}$ Orrick was a Democrat, but was a compromise appointment in a political deal to appoint judges from both parties. (Orrick, 1989, pp. 244-250)
} 
fulcrum" (p. 286) and "most important branch of the government" (p. 283). He disapproved of being a "judicial activist" but admitted he had acted so in numerous major cases (p. 279). "When we look at what the executive branch is not doing and what the Congress is not doing," he lamented, "in order to continue the great country that we have, the federal judiciary has to take on that kind of power" (p. 280).

Judge Orrick faced a seemingly intractable problem when he took on San Francisco's school desegregation case in 1979. He noted that San Francisco schools had been "segregated since 1850 " (Orrick, 1989 , p. 274) $;^{30}$ but he also believed he uniquely had the tools in his courtroom to solve this problem. First, he was a staunch believer in the important role of attorneys as "problem solvers," helping "society stick together" (p. 283). Specifically, he recalled: "The counsel that I had in this case were skilled at it. In fact, they spent their entire time going around the country prosecuting and defending these cases. So, rather than take a strong activist position, I thought I would let them dispose of the case in the manner that seemed fair to them" (p. 271). Second, Judge Orrick used his stature on the federal bench and his Washington connections to recruit the court's own "Panel of Experts" co-chaired by former U.S. Commissioner of Education Harold Howe II, and Dr. Gary Orfield, "one of this country's most relentless supporters of school integration" (Levine, 2000, p. 46, fn28). The judge affectionately dubbed them his "Committee of Wise Men". They held meetings all "around the country," and issued a "superb report" in summer 1982 which became the roadmap and outline for the Consent Decree settlement enacted in 1983 (Orrick, 1989, p. 273).

Judge Orrick handled some of the most celebrated cases in the Northern District (Holding, 2012; Orrick, 1989), but his judicial philosophy always focused on settling cases without the confrontation of a trial. "If you want fair treatment, you split the difference," was Orrick's advice to his clients since his first appearance in the courtroom (Orrick, 1989, p. 59). In this instance, however, there had been such a long history of racial segregation and so many failed attempts to desegregate, that the Black community and integration advocates did not trust that any plan agreed to would actually be enacted. For the NAACP to accept the Experts Report as the framework for a settlement agreement, the report's action plans and recommendations would need to be codified in a legal consent decree signed by Judge Orrick. NAACP insisted: "this Court must stay actively involved with the implementation process so that the goals of the Decree become a reality" (Quinn, 2020, pp 127-128). ${ }^{31}$

The NAACP's vision for the role of the court matched Judge Orrick's ambitions for wielding the power of the federal judiciary. NAACP attorney Peter Cohn singled out Orrick's key role: "(Judge Orrick) said to us, basically, you can trust me, I give you my word, that if you settle this case, I will enforce the law and the Constitution.... It was the closing of the deal that the presiding judge tells you ...(he's) going to attend to it" (Cohn, 2020). Judge Orrick recruited one of the top national law firms to draft the consent decree based on the Experts Report. He appointed Professor Orfield as Consent Decree Monitor (Cohn 2020; Orrick, 1989; Quinn, 2020). SFUSD was tasked with implementing programs both to integrate all schools, and to improve academic performance of all students (Levine, 2000; San Francisco NAACP v. San Francisco Unified School District, 1983). The State of California was ordered to fund all of the programs (Levine, 2000, pp. 46- 47, fn39). And as a final touch, SF NAACP was certified in 1983 as class representative to represent not just Black students, but all San Francisco public school students, since all students "sought as a common objective ... complete desegregation"

\footnotetext{
${ }^{30}$ Orrick added (1989, p. 275): "Of course, it's easy enough to find in Hunters Point". Hunters Point is historically a predominantly black neighborhood of San Francisco. According to the U.S, Census, the black population was $72.97 \%$ in 1980 (Bowser, 1988, p. 383).

${ }^{31}$ The California governor's office first pledged to investigate the issue in the late 1950's, and "started us on a long road, twenty years and more," trying to end school segregation, stated Grandvel Jackson, who was president of NAACP in 1959 (Quinn, 2000, p. 127-128).
} 
of the city's public schools (Levine, 2000, pp. 50-51, fn64; San Francisco NAACP v. San Francisco Unified School District, 1983)..$^{32}$ One of Judge Orrick's sayings was, "Hard cases make bad law" (Orrick, 1989, p. 157). But in this case, he felt he had truly fulfilled his "responsibilities in the administration of justice" (p. 286). Four years later, after receiving "periodic reports" from the school district, Judge Orrick assessed the SF Schools Consent Decree as "a great success," adding for emphasis, "a definite success" (p. 277).

Judge Orrick's role in desegregating San Francisco schools was important to him. All of his work to advance the civil rights movement was important to him. ${ }^{33}$ His life centered around politics and his profession was the law. But his law works always dealt with business and corporate matters. He had hardly tried any cases in a courtroom. ${ }^{34}$ His civil rights work was his chance to take action, do good and help "society stick together" (Orrick, 1989, p. 283). When he first went down to Alabama in 1961 as an Assistant U.S. Attorney to protect the Freedom Fighters from violence by the Klu Klux Klan and conservative white supremacist police, he had not had any experience in dealing with black/white race relations. But he volunteered to be part of Attorney General Bobby Kennedy's special unit out of a sense of "team spirit", and felt comfortable about it since none of the other deputized special agents knew "much more about civil rights than" he did (p. 123). In fact, Judge Orrick didn't know much about America beyond his rarefied upbringing in the most privileged neighborhoods of San Francisco and Berkeley (the gated home compound he grew up in spanned a "large city block" (p. 3)). Until he travelled back East for his last year of boarding school, Orrick had never himself witnessed the existence of "poor people" (p. 23). "We just didn't see it," Orrick explained (p. 28). The experience "made a lasting impression" (p. 28). These were Black Americans during the Great Depression of the 1930s in New York City's slums. "I could never understand, ... why, with the enormous surpluses of wheat and other grains in this country and others, tens of thousands of black Africans are starving," Orrick would tell friends (p. 28). ${ }^{35}$ As a young college student, he studied President Franklin Roosevelt's New Deal as a way to "solve" the problem. Judge Orrick believed that even if issues like civil rights were not always a "legal problem" (p. 280), he could "use the power of the court to effectuate resolutions" for society's "administrative and political" problems as well (Cohn, 2020).

It was 1987 when Judge Orrick so confidently declared the School Consent Decree a success. Change had indeed begun, and a decade into implementation, those changes became institutionalized and "embedded" programs and racial quotas (Campos, 2020). The relationship between the players changed too. The school district and the NAACP who had been "antagonists" in the courtroom, were now "partners in this consent decree" (Campos, 2020). The two organizations worked together "shoulder to shoulder" in bringing desegregation to SF public schools (D. Levine, personal communication, March 10, 2020). The school district was

\footnotetext{
${ }^{32}$ Levine (2000) notes class certification was unusual to happen at the end. Also, Peter Cohn (2020) recalls: "Before the case was settled right before, the judge said that based on the experience of the individuals in our team, our team led by Nate Jones and Tom Atkins, who was the lead counsel on the legal team out of New York. He said that, really based on your experience with school districts across the United States, would you be willing to represent all the children in the San Francisco Unified School District?"

${ }^{33}$ Ironically, the only opposition to his appointment as federal judge came from the "Charles Houston organization, which opposed my nomination because I wasn't black." (Orrick, 1989, p. 247)

${ }^{34}$ Orrick recalled: "I tried a couple of cases" and also laments: "I would have enjoyed more trial work than I had." (Orrick, 1989, p. 59, 250)

35 The only time the word African is used in his entire oral history is in this recollection of slums and Black Africans. "We didn't see people in rags. We didn't see a man in tattered overcoats selling apples, literally. We just didn't see it. When it came upon me, as it did for me when I first went to New York, it made a lasting impression." $(27,28)$
} 
even paying the legal fees for the NAACP attorneys as mandated by federal law, so "there was a relationship built" (Campos, 2020). ${ }^{36}$

\section{Figure 3}

(a). Photo on the top left is first generation William Horsley Orrick, Sr. who founded Orrick law firm in 1863. In 2019, the firm had over \$1 billion in revenue (Bickle, 2016).

(b). Photo on top right is third generation William Horsley Orrick III who took office as United States District Judge of the United States District Court for Northern District of California in 2013 (Bickle, 2013).

(c) Photo on the bottom is William Horsley Orrick Jr. (center) with Boddy Boddy Kennedy and Justice Potter Stewart at his swearing-in as chief of the Civil Division of Department of Justice in 1960. (Orrick, 1989).

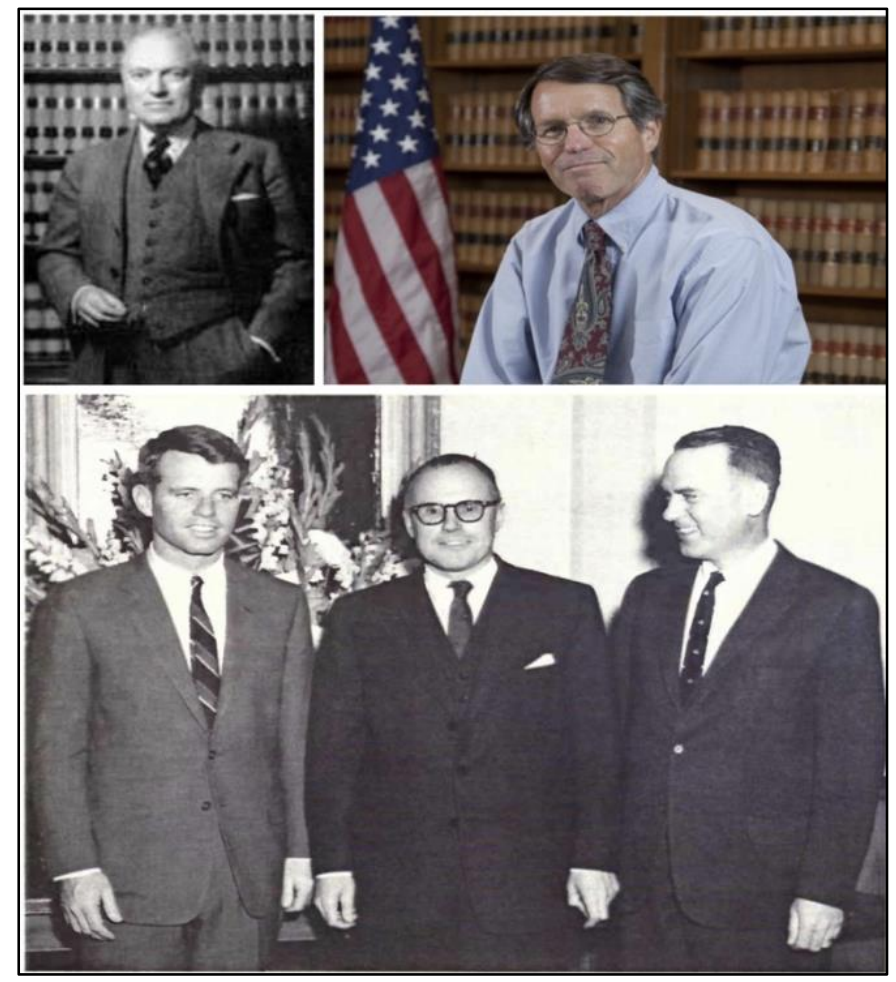

But one thing had not changed. It was that Chinese families were an afterthought, bringing up the rear as events moved ahead. During NAACP's first 1969 suit, Chinese families sought to make their voices heard, but their petition was dragged out and never ruled on (Levine, 2000, p. 42, fn11). Those Chinese petitioners filed their application late, had their petition rejected, then reinstated on appeal, and ultimately rendered moot when the case was dismissed and replaced by Judge Orrick's 1983 Consent Decree. (Johnson v. San Francisco Unified School Distrrict, 1974). The parents in 1971 were more driven by white mainstream politics, as their case was brought by the legendarily bombastic and conservative Quentin Kopp, who was making his first run for city Supervisor that year (Kopp, 2001, p. 157-162). ${ }^{37}$ The new 1990s parents, however, were driven by Chinese American politics and the community's quest for

\footnotetext{
${ }^{36}$ Campos continues: "And so there was a relationship that was built and then you have the Ho litigants coming in and saying, hey, what you're doing is unconstitutional, it's wrong."

${ }^{37}$ Anti-bussing was part of Kopp's campaign platform and he held his kick off in Chinatown where the concentration of Chinese residents meant there would be a concentration of Chinese students, many of whom would have to be bussed across town to meet desegregation requirements. Kopp won his election, the first of four terms as City and County Supervisor (Kopp, 2001).
} 
self-determination (S. Wong, personal communication, February 12, 2020; L. H. Lee, personal communication, March 20, 2020).

Orrick was not familiar with the way this new breed from the Chinese American community was challenging him. As much as the sight of the slums of New York City influenced his attitude to help poor "Black Africans" (Orrick, 1989, p. 28), there were only two Asians in his growing up that made any impression on Judge Orrick at all. One was the oneeyed "Chinese cook," who Orrick recalled even in his later years: "We would taunt him about his eye until he picked up a meat cleaver and started after us. Grandmother, needless to say, did not approve of this, and she soundly lectured us" (p. 13) Orrick also remembered "the Japanese gardener" who took care of the massive grounds of the family compound. Orrick would again "get in trouble" with the gardener for playing football with his friends on "the big lawns" (p. 23). Perhaps Judge Orrick thought he could deal with the Chinese parents in a similar fashion. David Levine, one of the lawyers for the Chinese parents said it felt like Judge Orrick was "biding his time until he" might find a way to make their case "go away" (D. Levine, personal communication, July 29, 2020).

The new arguments made by these Chinese parents were a "combination of surprising and stinging" to Judge Orrick. He had not heard major disputes in this case since the early days of implementing the consent decree. Since then, all the sides had been in agreement. Levine (2020) recalls it was like "there was this little club." Together with the judge, the lawyers for the school district and NAACP "had settled a tough case. So of course, they thought they were doing good". They all wanted things to work out. They had no "incentive to bring up thorny issues" (T. Lee, 2020) They kept "telling the judge everything was fantastic" (Levine, 2020). So naturally, Judge Orrick appeared "quite skeptical" of the Chinese parents when they zeroed in on the consent decree as being unfair and illegal (T. Lee, 2020).

Amy Chang, the Chinese parents and activists were on a whole different page. "The law was overwhelmingly on our side," insisted Lee Cheng (2019), "Unequivocally". Even those parents not familiar with the law were resolute. Victor Seeto (2019) recalls "Our attorneys expressed confidence. We did not doubt their judgement ... We felt our cause was right." 38 In fact, the law had been shifting rapidly. California voters passed Proposition 209 in 1997, banning all forms of affirmative action, with similar initiatives soon passed in Washington State (1998) and Florida (2000) (Brunner \& Rowen, 2021). On the federal level, the U.S. Supreme Court in 1995 raised the bar by establishing "strict scrutiny" for use of affirmative action measures and new limits on remedies for racial discrimination (Adarand Constructors, Inc. v. Pena, 1995). A second 1995 ruling (Missouri v. Jenkins) further helped "delink issues of racial justice... from issues of public education" (Fitzgerald, 1996, p. 39). In 1996, the U.S. Fifth Circuit Court of Appeals struck down race as a factor that could be considered in Hopwood v. Texas. ${ }^{39}$ But in San Francisco, Consent Decree participants remained focused on long-term future goals and remedying past inequities. The Chinese parents homed in on how race relations were rapidly changing in the present time of the 1990s. They ran their case like a project: raising funds, recruiting lawyers, meeting regularly. "We were managing a project, and we had people who (were) very, very good at managing projects," recalls Lee Cheng (2019).

When the tide finally did turn against the consent decree in 1998, it was definitive. The reversal came in two decisions from the U.S. Ninth Circuit Court of Appeals (Ho, Order, 1998; Ho vs U.S., 1998). In effect they ruled that Judge Orrick had overstepped his bounds and exceeded his judicial authority. Judge Orrick had wrongly used his power and "the protection of the court" (Levine, March 2020) to shield the consent decree. ${ }^{40} \mathrm{He}$ had modeled the consent decree on the Experts Report written by his nationally-renowned educational professionals. But

\footnotetext{
${ }^{38}$ Lee Cheng (2019) explained: It "was just clear this was a winner in court"

${ }^{39}$ The U.S. Supreme court did not override Hopwood until 2003 (Grutter v. Bollinger).

${ }^{40}$ The appellate court "pretty much told (Judge Orrick): 'you got that completely wrong"” (Levine, March 2020).
} 
the educational standards of the Experts Report did not satisfy the legal standards for enforcing the consent decree. Constitutional attorney David Levine for the Chinese parents (March 2020) described it as if the Panel of Experts "had a seminar at Harvard" and said "to heck with the law, let's just focus on what's educationally wise". For his part, Professor Orfield bitterly objected that the "entire effort would be junked ... by a group of lawyers" (Ho v. San Francisco Unified School District, 1999, DF404; Quinn, 2020).

Judge Orrick was admonished by the Appellate Court but not cowed. He was employing methodology that had brought him so much success over his career. "Law is experience," was Orrick's motto (1989, p. 150). ${ }^{41}$ At the Department of Justice, he used the resources and influence of the government to assemble the best experts to solve the problem and then he used the weight and power of federal law for enforcement procedures. ${ }^{42}$ Now, as a United States Judge, he applied this method to creating the San Francisco Schools Consent Decree. Orrick moved to bring back his experts to make the case that his use of judicial power was needed and justified. He appointed his own Special Master to collect evidence and validate his actions (Ho, Order, 1998; Levine, 2000). ${ }^{43}$ But he was stopped. The appellate court stepped in again with a second ruling not more significant, but vastly more devastating (Ho vs U.S., 1998). The appellate Justices did not mince words describing Judge Orrick as having "interfered in the adversarial process" (Levine, 2020, p. 75). ${ }^{44}$ "They basically read him the riot act," recounted Louis Hop Lee (2020). The Appellate Court labelled Judge Orrick's appointment of the Special Master as "improper", directed him into "immediate compliance" with the Appellate Court's instructions, and ordered him to hold a trial immediately on the validity of the consent decree. It was a near unprecedented calling out of a Federal Court Judge, causing even Judge Orrick to refer to it as a "peculiar order" (Levine, July 2020). ${ }^{45}$

As the Appellate Court undercut Judge Orrick's power to hold the consent decree together, the parties also began dividing again (Levine, July 2020). ${ }^{46}$ The SF school district brought up old worries about the cost and coordination needed to implement the desegregation and educational programs, and the NAACP became wary once more about some schools falling back and being dominated by one race of students (Levine, 2000; Quinn, 2020). ${ }^{47}$ The school

\footnotetext{
${ }^{41}$ Undoubtedly, as Justice Holmes said, law is not logic; law is experience. And those experiences impacted on me in the way I have described previously. I think it has been of help." (Orrick, 1989, p. 285)

${ }^{42}$ Orrick recalled: "In 1963 I settled a big case for the government, the I.G. Farben case, and I am going to use some of the same methods on you that I did on them". Orrick even recruited presidential advisor Lloyd Cutler (whom he called 'perhaps the best lawyer in the country') to serve as his personal representative to lead settlement negotiations- or as Orrick referred to him, his "amanuensis". (The Farben matter had gone on since the end of World War II, with the U.S. repatriating Germany for improperly seized wartime assets. Orrick helped settle the case during his time as Deputy Attorney General pursuing the same dual track strategy of preparing for a trial and personally overseeing high-powered settlement negotiations. The Farben settlement also had some controversy when it became an issue for Bobby Kennedy's presidential campaign (Orrick, 1989, pp. 271, 274, 146).

${ }^{43}$ See also: Order, Ho v. San Francisco Unified Sch. Dist., (N.D. Cal. Sept. 23, 1998) (No. C-94-2419-WH)

${ }^{44}$ See also Order at 2, Ho v. United States Dist. Court (9th Cir. filed Dec. 14, 1998) (No. 98-71415

45 David Levine (July, 2020): "I remember him calling it a peculiar order. That was the most he ever said but he did use the word peculiar. So, he was not happy. And what he interpreted it as: All right, the parties, they're just going to have to deal with this themselves, no more help. And we filed an additional motion for summary judgment because, you know, we saw the other side was collapsing. It's like, 'Come on, let's get this up'. And Orrick said 'no, the Ninth Circuit wants a trial by golly they're gonna have a trial'. So, he rejected our renewed motion for summary judgment saying basically, 'I'm not going to get in trouble with the Ninth Circuit again'. So yeah, he was stung. He was stung."

${ }^{46}$ The State of California itself split its position and representation as Republican Governor Pete Wilson hired attorneys to side with the Ho plaintiffs while Democratic Superintendent of Education Delaine Eastin retained attorneys to seek middle ground (Levine, 2000, pp. 96-97)

${ }^{47}$ David Campos (2020) recalled: "the hardest thing was that once you eliminated those then you saw schools resegregating"; and according to David Levine (March 2020): the NAACP "was appropriately pushing the school board. It was the job of Peter (Cohn) to push the school board".
} 
district was having second thoughts about getting into a trial that would justify the consent decree by rehashing past ugly discriminatory practices in the schools. That would "expose the school district to all kinds of liability" (Levine, July 2020). This created a "further big fissure" with the NAACP lawyers who now had to fight both the Chinese parents' frontal legal assault, and also face the school district's weakening support on their backside (Levine, 2000, p. 94). ${ }^{48}$

On the morning of the first day of the trial, the Chinese parents walked into the Federal Courthouse building, ready to hear opening arguments (Levine, 2000). The courtroom was packed. Folks were expecting "dramatic testimony" that might "totally change affirmative action in the United States" (D. Levine, personal communication, October 27, 2020). But instead, the attorneys huddled to the side, and an hour later, all the attorneys came out of the courtroom together. They announced that a settlement had been reached! (Cohn 2019; T. Lee, 2020; Levine, March 2020) 49 "We won everything," exclaimed Lee Cheng, "We were very happy." "They caved," echoed Louis Hop Lee. "We had no choice but to accept," added Lee Cheng (Cheng, 2019; L. H. Lee, 2020). ${ }^{50}$ Virtually all of the terms of the Chinese parents had been met (SFNAACP, 1999; Levine, 2000):

- SFUSD was to "remove the racial/ethnic guidelines immediately" that had limited Chinese students in some schools

- SFUSD would no longer use "race or ethnicity." to "admit or assign" students

- Race and ethnicity banned as "primary or predominant consideration" in "admissions criteria"

- SFUSD could "request, but not require" information about race or ethnicity

- The Chinese parents could review, but not veto, the new SFUSD student assignment plans

It was a win-win-win. Even NAACP considered the settlement satisfactory (Cohn, 2019), ${ }^{51}$ mainly because, despite all the concessions, everything else about the consent decree remained intact, and ultimately was extended through 2005 (SFNAACP, 1999). ${ }^{52}$ The SF School District had also been "very focused" on extending the consent decree. This was due to the huge financial impact. While the Chinese parents were not fighting over school funding (T. Lee, 2020; Levine, March 2020) the other parties were "focused on losing the money" (Levine, March 2020). In 23 years, the consent decree directed more than half a billion dollars be spent on integrating San Francisco schools and improving academic performance of all students (Table IV; Quinn, 2020, pp. 265, fn199) ${ }^{53}$ Much of the funding went to programs trying to

\footnotetext{
${ }^{48}$ The SF Board of education no longer wanted to favor NAACP over the Chinese families "really shifting to say ... we can't do that, we have to be an arbiter" (Campos, 2020); Also: "by and by the state defendants peeled off and decided not to defend. And when that happened shortly thereafter, the school district decided not to defend" (Cohn, 2019); See also Orrick's remarks after the case settlement: Opinion \& Order, Ho v. SFUSD. 59 F. Supp. 2d 1021 at 25.

49 "it was a surprise when we had this last second settlement" (Levine, October 2020). But the settlement also was a long time coming. Levine (2000, pp 94-104) discusses the fits and starts to negotiations, and as noted supra fn 41 changes to the legal landscape also forced the defendants' hand.

50 "It was an unequivocal tactical home run," added Lee (2019)

${ }^{51}$ This paragraph discusses the local implications of the settlement. There were also potentially favorable national implications for NAACP. NAACP was involved in all the lawsuits nationwide and were able to choose which cases to move forward. According to Lee Cheng (2019) "They cherry pick what advances .... cases with fact patterns that are favorable to what they need to defend. ... They just basically pushed settlements in all the cases (with) bad fact patterns. And it's really very strategic, highly admirable. And it's not just money. They're smart, really, really, really smart lawyers."

${ }^{52}$ The 1999 settlement ended the consent decree in 2002 but this was extended until 2005, another requested extension was denied by newly assigned Judge William Alsup (Orrick retired in 2002) (Levine, 2003, p. 511).

${ }^{53}$ Henry Der (2004) stated: "SFUSD has received more than $\$ 30$ million in state funds annually"
} 
improve the education of Black and Latino students. ${ }^{54}$ Millions were also spent on monitoring and enforcing the consent decree, including attorneys and professional fees for NAACP, and expert fees for the Panel of Experts. ${ }^{55}$ The extension of the consent decree gave SF officials extra time to negotiate a new funding mechanism from the State of California to fund desegregation programs (Campos, 2020). This funding contributed 10-12\% of the entire schools' budget (Levine, March 2020). ${ }^{56}$

For the Chinese parents, the amount of money being spent on consent decree programs was mind-boggling. ${ }^{57}$ They first noticed that all the players in the SFUSD case were of national stature. Then they came to understand that there were up to "500 of these consent decrees" across the nation, many represented on both sides by the same national lawyers and experts involved in the San Francisco case (Cheng 2019). Many of the Chinese activists became very disillusioned that there was a "diversity industry" or what some of them disdainfully called a "racial preference industry" being supported with billions of taxpayer dollars (Cheng 2019). Still, most Chinese parents were "pragmatic" in supporting San Francisco's consent decree's extension (Levine, March 2020). In fact, the consensus to continue the consent decree was a point of pride for the previously antagonistic litigants (Campos, 2020). NAACP attorney Peter Cohn $(2019,2020)$ noted "an interesting evolution" in the Chinese parents' attitude towards the consent decree once the racial quotas were removed as an issue. NAACP was "very happy" that the parents realized it was in the "interest" of Chinese students as well, to fund programs promoting academic excellence and diversity such as bilingual access. Added Levine, attorney for the Chinese families: "who's going to be opposed to that?" (March 2020). ${ }^{58}$

So that's how this story ends. The Chinese parents seemingly won everything they could ask for. But strangely, Amy and some of the others weren't that happy. ${ }^{59}$ There were victory parties. The Chinese American Democratic Club held another community banquet and issued special awards to the legal team. But Louis, Amy and Harrison were left with a bitter aftertaste, feeling that liberals and democrats had used racial strife as a canard to create the consent decree. All of them followed the lead of Lee Cheng and switched their politics to the Republican party (L. H. Lee, 2020; H. Chow, March 2020; Cheng, 2019). The lawsuit also continued to have a mixed impact on Amy's life. Although she passed the bar and became an up-and-coming corporate attorney, she found she didn't want to practice the law after all. Her husband, Harrison, never fully understood why Amy would walk "away from something she was successful at" $(\mathrm{H}$. Chow, personal communication, October 22, 2020). Amy still had the fight in her, she just didn't believe in the corporate or legal fighting. ${ }^{60}$ In 2013, when she and Harrison had bought

\footnotetext{
${ }^{54}$ For example, one elementary school was "enriched to place an emphasis on computer instruction", another high school implemented an "academically rigorous program to attract students". Many others were "reconstituted" as magnet schools, model schools and academic schools. (Goldstein, 1998, pp. 1-3)

55 See also: Campos (2020); Cheng (2019); Cohn (2019); Lee (2020); Levine (March 2020; October 2020); H. Liddell (personal communication, October 23, 2020)

${ }^{56}$ Levine (2020, pp 54, fn88) discusses controversy over massive consent decree expenditures: "It Isn't About the Children Anymore".

${ }^{57}$ Lee Cheng (2019): "The money that they were getting from all the consent decrees ... literally hundreds of millions of dollars a year and cumulatively billions of dollars a year ... these assholes just completely took public money. ... they're just corrupt jackasses"; From Harrison Chow (March 2020): "It was just a bunch of corrupt guys in it for the money. ... It was just about the money. They wanted to administer desegregation where it made no sense at all"; see also Louie (2019); L. H. Lee (2020).

${ }^{58}$ Everyone agreed "getting money to improve the schools" was generally a good thing (Levine, March 2020).

59 "We didn't win strategically, who knows who will win in the long run?" (Cheng, 2019).

${ }^{60}$ Amy's friend Tony Lee also had a successful law career, and also decided to give it up. Tony (2020) summed up his ambivalence this way: "I'm glad I did it. I'm also glad I'm not doing it anymore." He also used temporal terms to describe it further like that old "cliche": "If you're young and not liberal, you have no heart. If you're old, and you're not conservative, you have no brain. But I mean, to some extent, I think people, they get more conservative as they get older..."
} 
a condo to retire in their older years, the city government suddenly decided to build a shopping center across the street with a huge Target discount store in front of their window. ${ }^{61}$ Amy the fighter came to the fore again. She protested the development and made waves. The city planners and developers gave in to Amy and planted a whole row of redwood trees between the shopping center and their condo development. "It's pretty remarkable ... to see those trees ... and know why they are there," recounts Harrison (Chow, October 2020).

Table 4

State of California Spending on SFUSD Desegregation Programs $\$ 50,000,000$

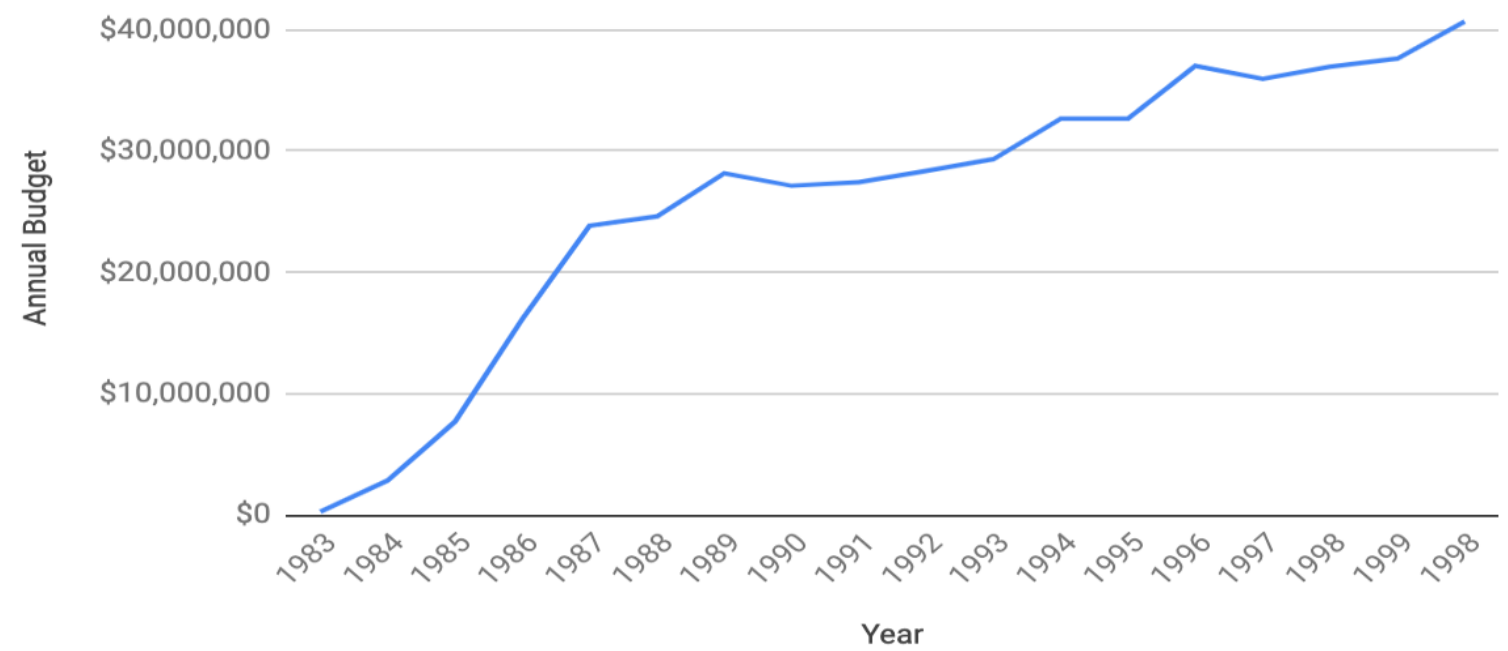

\begin{tabular}{ll}
\hline Year & Annual Budget \\
\hline 1983 & $\$ 285,942$ \\
1984 & $\$ 2,859,423$ \\
1985 & $\$ 7,710,382$ \\
1986 & $\$ 16,162,164$ \\
1987 & $\$ 23,848,651$ \\
1988 & $\$ 24,621,372$ \\
1989 & $\$ 28,176,087$ \\
1990 & $\$ 27,148,880$ \\
1991 & $\$ 27,439,016$ \\
1992 & $\$ 28,377,170$ \\
1993 & $\$ 29,340,000$ \\
1994 & $\$ 32,676,000$ \\
1995 & $\$ 32,676,417$ \\
1996 & $\$ 37,029,604$ \\
1997 & $\$ 35,952,302$ \\
1998 & $\$ 36,950,429$ \\
1999 & $\$ 37,624,000$ \\
1998 & $\$ 40,682,362$ \\
\hline Total & $\mathbf{\$ 4 6 9 , 5 6 0 , 2 0 1}$ \\
\hline
\end{tabular}

Note. Data is taken from Defendants' 1998-1999 Annual Report.

${ }^{61}$ The Main Street Cupertino Mall broke ground in September 2013 (Mercury News, 2013) 
As for the school assignments issue, Amy was somewhat disillusioned (Chow, March 16, 2020). She moved out of San Francisco and raised her three sons in the suburbs, so the issue never directly impacted her (Chow, 2018). But she was always "suspicious" of the settlement (Levine, October 2020) ${ }^{62}$ and believed the school district, NAACP, and their lawyers would just design another "disguised racial quota system" harming Chinese students (T. Lee, 2020). Feeling "dissatisfied" and worried that this "would be an ongoing battle", she, Lee Cheng, Roland Quan, Louis Hop Lee, Alan Tse, and Henry and Denise Louie, set up a new organization, the Asian American Legal Foundation to be a "watchdog group" to fight against new school assignment policies that would harm Asian American students (Chow, September 2020). Amy supported AALF but let the others take the lead (H. Louie, 2019). In 2016, Amy lost a long battle with cancer and passed away at the young age of 54 (Chow, 2018). ${ }^{63}$ AALF has continued to file briefs against schools whose policies AALF considers harmful to Asian students, including cases against Harvard University, University of Texas, Michigan University, and others (Asian American Legal Foundation, 2018).

Ironically, in 2020, prompted by the COVID pandemic, Lowell High School went to a lottery system for most admissions. Students applying to Lowell were all lumped together and individuals selected at random for admission (San Francisco Board of Education, 2020). ${ }^{64}$ Ranked one of the nation's top academic high schools, and facing one of the greatest challenges in racial diversity, ${ }^{65}$ Lowell effectively eliminated both merit-based and race-based admissions (US News and World Report, 2020). The problem of student assignments for Lowell, and indeed America's entire educational system, remains unresolved. And it continues to be redefined by successive generations. Admissions to America's Ivy League Universities like Harvard and Yale have become a national issue for presidential campaigns (Han, 2020; U.S. Department of Justice \& Durham, 2020; Wermund, 2018). The U.S. Supreme Court is expected to continue hearing new cases and make new rulings on what is fair and constitutional (Allen, 2020). "The harsh lesson of school desegregation is that desegregation alone has not translated into equal outcomes for all students," Henry Der noted (Der, 2004, p. 308). "It's a never-ending bind," added Louis Hop Lee (L. H. Lee, 2020). Carol Kocivar, former President of the California Parent Teacher's Association and a long-time educational advocate in San Francisco, headed a task force trying to solve these problems. "Everyone had a position," Kocivar recalled, "People of all persuasions felt very strongly about it." And the parameters of the issue continued to evolve over time, with changing laws, changing demographics and changing politics. "I would say it is a constant issue of does the assignment system work? ... There's always controversy over what is the best way to meet the needs of kids," Kocivar concluded (C. Kocivar, personal communication, March 25, 2020).

\section{Discussion and Conclusion}

Kocivar is right in how the school assignments issue is ever changing. It reminds us of the temporal dimension of the matter - in other words, the different historical perspectives

\footnotetext{
${ }^{62}$ Levine (October 2020): "Well, I think that she was suspicious, let's say, I mean, because it was just so sudden" when SFUSD and NAACP agreed to settle on the first day of trial (Levine, 2003). Levine (2000, pp. 108-116) discusses the Ho attorneys' opposition to what SFUSD first proposed - which included consideration of race - and the second, acceptable, proposal which was enacted.

${ }^{63}$ Harrison said Amy kept news about her cancer "really private. She really did not want that out there."

${ }^{64}$ The lottery system for Lowell became permanent in 2021 (Bay City News, 2021)

${ }^{65}$ In 2020, Lowell's student body was 2\% Black, 11\% Hispanic, 18\% White, and 61\% Asian. (US News and World Report, 2020)
} 
motivating participants. ${ }^{66}$ Our research highlighted pioneering Asian American activists who acted in their "living present". ${ }^{67}$ They did not have a past in America and could not imagine the ramifications of this battle on their future. They were well educated about their American rights to fairness and equality. That was their American Dream and their motivation. But they also lacked the experiences of struggle and sacrifice which secured those rights of fairness and equality. Their complete American experience began as beneficiaries of the Civil Rights movement. We compared their perspective to that of the NAACP and Judge Orrick. NAACP's perspective was from America's past history: not only the generational experiences of slavery and oppression, but equally their past struggles and hard-won incremental victories. Judge Orrick, meanwhile, proceeded from a position of power and his perspective was to craft solutions that could adapt to "the future." "Nobody can tell (the future). But judges have to do it," Orrick once remarked.

\section{Figure 5}

Amy Chang \& Harrison Chow with sons ( $($ to r) Teddy, Adam, and Darwin - who were not yet born at the time of Amy's activism. (Chow, n.d.) Painting in background is Leland Stanford Jr. at Stanford University Museum. Amy was diagnosed in Feb 2016 with terminal lung cancer. (Chow, 2016).

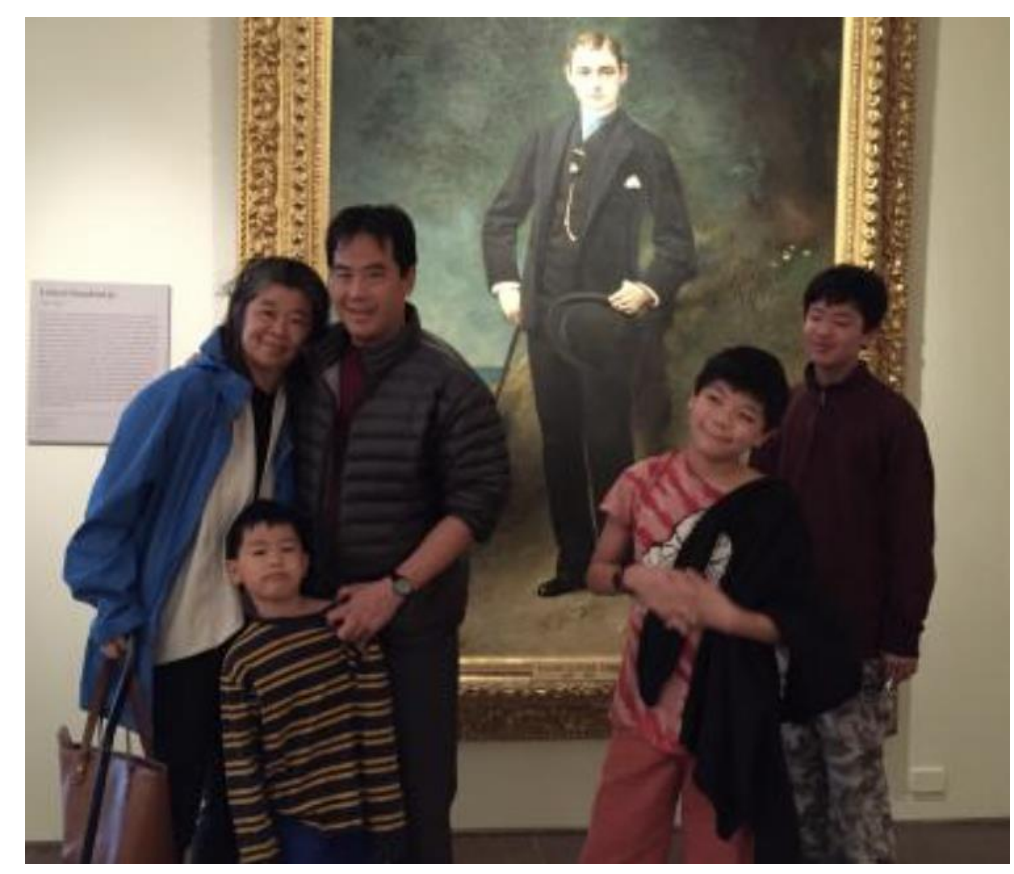

Our findings also showed that historical perspectives impacted methods. Asian American activists acted tactically. For example, when they thought politics could solve their issue, they registered voters and testified at public hearings, but when politics failed, they

\footnotetext{
${ }^{66}$ Deleuze (1995) posits three syntheses of time: Synthesis from perspective of the past; synthesis from perspective of the future; and synthesis from perspective of the present. Each synthesis in turn, has a different perspective on the three temporalities of past, present and future perspectives. Deleuze's work is evolved from Henry Bergson's $(1999,2001)$ theories and philosophy on time and duration. Felix Guattari (2015), also offers a practical framework (matrix) for political resistance. Deleuze and Guattari $(1983,1987)$ published together the two-book series Capitalism and Schizophrenia, an alternative philosophical, epistemological and practical methodology for change. ${ }^{67}$ In the present research this "living present" can be understood colloquially as "living in the present". For an academic treatment (see Robson, 2019): "Deleuze conceptualizes a "living present" in which both past and future are embodied in present affects, such as hope and fear of future illness, for example.” Also see Deleuze (1991, 1995), Walker (2014).
} 
quickly pivoted to the courtroom for redress. These novice community activists also took advantage of serendipity. From the start, it was unpredictable that someone like Amy Chang would arrive to lead the effort. And later, the class-action legal strategy was driven at least in part by the fact that the only attorney willing to accept the case happened to be a class action specialist. These practice methods can also be seen in their acts of resistance against being integrated into existing institutions. For example, the Chinese American parents resisted becoming drawn into the consent decree on either side; they refused to take funding from the consent decree programs to promote diversity; they were even ambivalent about being part of the legal profession, with two of them (Amy and Tony Lee) quitting the field of law altogether, while two others became respected corporate counsel (Alan Tse and Lee Cheng) ${ }^{68}$

This study expands the understanding of the role of Asian Americans in the debate over civil rights by providing a monograph of the Asian American experience fighting for school equity in San Francisco in the 1990s. It answers the call to document the agency and selfdetermination of the Asian American community (An, 2016; Chen \& Buell, 2018). As researchers fill in the historical gaps on Asian Americans (Hing, 1994; Okihiro, 2005; Quinn, 2020; Takaki, 1998, 2008; Wu, 2003; Zia, 2001), most studies still relegate Asian Americans to one side or the other (Black et al., 2020; Lee et al., 2020; Nelson et al., 2017; Nguyen et al., 2020; Students of Sociology of Asian America, 2019; Torres, 2020). Some studies have analyzed how the educational system and standards have influenced academia's discourse and understanding of Asian Americans (Chen \& Buell, 2018; Espiritu, 1993; Lee et al., 2020; Lew, 1995; Omi \& Winant, 1994), the present research is one of the first to directly demonstrate Asian American efforts, motivations and methods at developing and expressing themselves in the arena of civil rights.

A key limitation of this study is that it documents only one episode of Asian American activism. Additional monographs are needed to document: Asian American experiences in other urban and non-urban areas; the dynamics of diverse participation from other Asian nationalities; and the evolution of Asian American methodologies over time. Despite limitations, this study has shown that Asian Americans have agency, and are actively making their own histories. This study also offers some patterns to follow for groups wishing to make change outside traditional power and societal structures. For example: be focused on the present situation, detach from historical baggage or a predictable future, act tactically, and embrace serendipity.

The present investigation reveals that the methodologies employed by these Asian Americans resulted in an unpredictable future for them. This study again used a comparative analysis with the future results for the NAACP and Judge Orrick. From the NAACP's perspective of the historical past, they continued to expect the future to be the fulfillment of America's destiny as a nation of equality. Meanwhile Judge Orrick's focus on future-thinking solutions brought him a future that was actually more of an "eternal return," such that by the end of the case, Judge Orrick had returned to the cornerstone of his career, reinforcing the supreme power of the law. And a decade later, school segregation had returned to SF public schools with a vengeance: "a third of elementary schools were segregated, with at least 60 percent of students from the same race" (Tucker \& Knight, 2016).

The Asian American activists were the only ones really living and fighting their problem in the present. They didn't have a long-range strategic plan for the future. They won their lawsuit, but school assignment policies continued to evolve in unforeseeable ways (especially at Lowell High School). Even their own erstwhile law careers took unexpected turns. Because the Asian American community's tactics focused on acting in a living present, their future was

\footnotetext{
${ }^{68}$ In 2021, Alan Tse served as Global Chief Legal Officer and Corporate Secretary at Jones Lang Lasalle, and Lee Cheng was a shareholder at the Buchalter law firm.
} 
and continues to be the least predictable. The results of this study indicate that as the Asian American community continues to make its own present, their future always becomes the leading edge to the next chapter of the community's development.

\section{References}

Adarand Constructors, Inc. v. Pena, 515 U.S. 200, (1995).

Allen, J. (2020, October 14). Barrett reveals formula for reversing landmark rulings. NBC News. https://www.nbcnews.com/politics/supreme-court/barrett-reveals-formula-

reversing-landmark-rulings-n1243248

An, S. (2016). Asian Americans in American History: An AsianCrit perspective on Asian

American inclusion in state U.S. history curriculum standards. Theory \& Research in Social Education, 44(2), 244-276. https://doi.org/10.1080/00933104.2016.1170646

Ancheta, A. (1997). Race, rights, and the Asian American experience. Rutgers University Press.

Arcidiacono, P., Kinsler, J., \& Ransom, T. (2020, April). Asian American discrimination in Harvard admissions. National Bureau of Economic Research. https://doi.org/10.3386/w27068

Arkes, H., \& Dent, G. W. (2020). Holistic review in race-conscious university admissions [Faculty publication]. School of Law Case Western Reserve University: Scholarly Commons. https://scholarlycommons.law.case.edu/faculty_publications/2039

Asian American Legal Foundation. (2018, July 9). Asian American legal foundation. https://www.asianamericanlegal.com/

ASIAN, Inc. (2020, January 24). Statements by Board Chair Frank Fung and outgoing President Michael Chan. ASIAN, Inc. 美亞輔鄰社. https://www.asianinc.org/specialannouncement/

AsianWeek. (1988, August 19). Ben Tom 8 minutes behind deadline, kicked off ballot: Friday hearing to decide electoral fate of S.F. school board official. AsianWeek.

Asimov, N. (1992, June 27). S. F. Schools criticized on teaching of minorities. San Francisco Chronicle. p.A1

Asimov, N. (1996a, August 28). Lowell freshmen reflect new entry rules. San Francisco Chronicle. p. A1

Asimov, N. (1996b, November 3). Guardian at the school gate. SFGate.com. https://www.sfgate.com/news/article/SUNDAY-INTERVIEW-Guardian-at-TheSchool-Gate-2960586.php

Bay City News. (2021, February 10). SF school board votes to change admissions process for Lowell High School. NBC Bay Area News. https://www.nbcbayarea.com/news/local/sfschool-board-votes-to-change-admissions-process-for-lowell-high-school/2464739/

Bergson, H. (1999). Duration and simultaneity. Amsterdam University Press.

Bergson, H. (2001). Time and free will: An essay on the immediate data of consciousness (1st Ed.). Dover Publications.

Berkeley Historical Plaque Project. (2018). Berkeley Historical Plaque Project - Asian American movement birthplace. http://berkeleyplaques.org/plaque/birthplace-of-theasian-american-movement/

Bickle, Alex. (December 3, 2013). [Photograph]. Geni, My Heritage, Ltd. https://www.geni.com/photo/view/6000000048122552045?album_type=photos_of_m e\&photo_id=6000000048123899512

Bickle, Alex. (October 10, 2016). [Photograph]. Geni, MyHeritage, Ltd. https://www.geni.com/photo/view/6000000048122231398?album_type=photos_of_m e\&photo_id=6000000048122762027 
Black, S. E., Cortes, K. E., \& Lincove, J. A. (2020). Apply yourself: Racial and ethnic differences in college application. Education Finance \& Policy, 15(2), 209-240. https://doi.org/10.1162/edfp_a_00273

Bowser, B. P. (1988). Bayview-Hunter's Point: San Francisco's Black ghetto revisited. Urban Anthropology \& Studies of Cultural Systems \& World Economic Development, 17(4), 383. https://www.jstor.org/stable/40553136

Broussard, A. (1993). Black San Francisco: The struggle for racial equality in the west. University of Kansas.

Brunner, B., \& Rowen, B. (2021, January 26). Timeline of affirmative action milestones. InfoPlease. https://www.infoplease.com/history/us/timeline-of-affirmative-actionmilestones\#ixzz2fk1o1KYk

Budiman, A., \& Ruiz, N. G. (2021, April 29). Key facts about Asian Americans, a diverse and growing population. Pew Research Center. https://www.pewresearch.org/facttank/2021/04/29/key-facts-about-asian-americans/

Bunting, G. (1993, March 8) Senators reverse styles to match new roles: Politics: Dianne Feinstein's jump into the limelight is designed to boost bid in 1994. Barbara Boxer's low-key approach is a 'thank you' to her colleague. Los Angeles Times. https://www.latimes.com/archives/la-xpm-1993-03-08-mn-1605-story.html

Bush, D. V. (1984, July 16-19). Official proceedings of the 1984 Democratic National Convention. Democratic National Convention, San Francisco, California.

Cabading, C. (1983, January 20). Asians are the majority at Lowell High School: 64\% of student body at top-ranked institution. AsianWeek. https://proquest.com

CADC Special Events Cmte. (1993, February). CADC 35th anniversary banquet program booklet. Chinese American Democratic Club.

Calandra, T., \& Matier, P. (1989, August 21). The new city: Asian influence comes of age. SF Examiner. Proquest.com

Carlsson, C. (1994). WWII in-migration \& rising of bigotry. FoundSF.org. https://www.foundsf.org/index.php?title=WWII_In-migration_\%26_Rising_Bigotry

Chang, A. (1993, March). SF school district's consent decree (p. 1). Chinese American Democratic Club Fiery Dragon Newsletter.

Chang, B. (2017, May). Asian Americans and education (ED577104). ERIC. https://eric.ed.gov/?id=ED577104

Chang, R. S. (1993). Toward an Asian American legal scholarship: Critical race theory, poststructuralism, and narrative space. California Law Review, 81(5), 1241. https://doi.org/10.2307/3480919

Chao, E. (n.d.). Elaine Chao biography. Www.Elainchao.Com. Retrieved March 13, 2021, from https://www.elainelchao.com/biography/

Chen, G. A., \& Buell, J. Y. (2018). Of models and myths: Asian(Americans) in STEM and the neoliberal racial project. Race, Ethnicity \& Education, 21(5), 607-625. https://doi.org/10.1080/13613324.2017.1377170

Chinese American Democratic Club. (1987, March). Keynote speech by Supervisor John L. Molinari at annual dinner (p. 1). Chinese American Democratic Club Fiery Dragon Newsletter.

Chinese American Democratic Club. (1993a, March). Committee chairs (p. 8). Chinese American Democratic Club Fiery Dragon Newsletter.

Chinese American Democratic Club. (1993b, May). CADC and the consent decree (p. 1). CADC Fiery Dragon Newsletter.

Chinese American Democratic Club, Brief of Objections, San Francisco NAACP v. San Francisco Unified School District (N.D. Cal. filed April 22, 1993) (No. C-78-1445WHO). 
Chow, H. (2018, August 1). Amy Paayfen Chang (1964 - 2018). LastingMemories.Com. https://www.lastingmemories.com/memorial/amy-paayfen-chang?about

Chow, H. (n.d.). Amy Chang and family [Photograph]. Harrison Chow.

Civil Rights Division of the Department of Justice. (2021, March). Educational opportunities cases. United States Department of Justice. https://www.justice.gov/crt/educationalopportunities-cases\#race

Curtis, D. (1986, June 11). Top-rated Lowell a pressure cooker. San Francisco Chronicle.

Defendants' 1998-1999 Annual Report. SFNAACP v. SFUSD (DF1035, 8/4/99).

Deleuze, G. (1991). Bergsonism. MIT Press.

Deleuze, G. (1995). Difference and repetition (Revised ed.). Columbia University Press.

Deleuze, G., \& Guattari, F. (1983). Anti-Oedipus: Capitalism and schizophrenia. University of Minnesota Press.

Deleuze, G., \& Guattari, F. (1987). A thousand plateaus: Capitalism and schizophrenia (2nd ed.). University of Minnesota Press.

Der, H. (1994). Clash between race-conscious remedies and merit: School desegregation and the San Francisco Chinese American community. Asian American Policy Review, 4, 65. https://core.ac.uk/download/pdf/216982967.pdf

Der, H. (2004). Resegregation and achievement gap: Challenges in San Francisco school

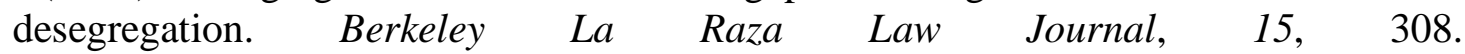
http://www.club.cc.cmu.edu/ scu/8202/resegregation_and_achievement.pdf

Desegregation and Education Change in San Francisco: Findings and Recommendation on

Consent Decree Implementation, San Francisco NAACP v. San Francisco Unified School District (N.D. Cal. filed July 1992) (No. C-78-1445-WHO).

Dong, S. (1995). "Too many Asians": The challenge of fighting discrimination against AsianAmericans and preserving affirmative action. Stanford Law Review, 47(5), 1027. https://doi.org/10.2307/1229181

Dougan, M. (1998, August 10). Fearless 'NAACP Chief Lulann McGriff dies. SFGate. https://www.sfgate.com/news/article/Fearless-NAACP-chief-Lulann-McGriff-dies3075191.php

Downey, Duke. (June 5, 1958). [Photograph]. SF Chronicle. https://opensfhistory.org/news/2020/06/14/the-san-franciscans-cecil-f-poole/

Edsall, T., \& Johnson, H. (1984, June, 2). Asian Americans torn between two parties. The Washington Post. https://www.washingtonpost.com/archive/politics/1984/06/02/asianamericans-torn-between-two-parties/78b84224-8526-48b4-8f21-7fc10c677b61/

Espiritu, Y. (1993). Asian American panethnicity: Bridging institutions and identities (1st ed.). Temple University Press.

Fernandez, E., \& Walsh, D. (1989, December 17). SF schools bickering continues, San Francisco's battling Board of Education. San Francisco Examiner. www.proquest.com

Fitzgerald, L. S. (1996). The constitutional amendment by Missouri v. Jenkins. Washington \& Lee Journal of Civil Rights \& Social Justice, 2(1), 39. https://scholarlycommons.law.wlu.edu/crsj/vol2/iss1/7

Frum, D. (2000). How we got here: The '70s. New York Basic Books. https://archive.org/details/howwegothere70sd00frum/page/252/mode/2up

Fuchs, C. (2016, December 1). Elaine Chao's cabinet nomination brings 'pride for some in U.S., overseas. NBC News. https://www.nbcnews.com/news/asian-america/elaine-chao-scabinet-nomination-brings-pride-some-u-s-n690071

Fulbright, L. (2009, February 16). Some S.F. African American history landmarks. San Francisco Chronicle. https://www.sfgate.com/bayarea/article/Some-S-F-AfricanAmerican-history-landmarks-3250887.php 
Gatson, Clarence. (1985). [Photograph]. Geni, MyHeritage, Ltd. https://www.geni.com/people/William-Orrick-Sr/6000000048122231398

Goldstein, J. (1998, April). Reconstitution in theory and practice: The experience of San Francisco (ED427991). Annual Meeting of the American Educational Research Association, San Diego, California. https://files.eric.ed.gov/fulltext/ED427991.pdf

Graubard, N., King N., Oliver L., \& Thomas, M. (1975, December 31). Title IV of the Civil Rights Act of 1964: A review of program operations. RAND Corporation. https://www.rand.org/pubs/reports/R1901z2.html.

Greene, L. (1989, October 2). Busing plan in peril as Chinese Students tilt balance in S.F. San Francisco Chronicle, A1.

Grutter v. Bollinger, 539 U.S. 306 (2003).

Guattari, F. (2015). Lines of flight: For another world of possibilities (Impacts). Bloomsbury Academic.

Han, W. (2020, August 17). For Asian-Americans, the Trump administration's attack on affirmative action presents a Faustian bargain. South China Morning Post. https://www.scmp.com/week-asia/opinion/article/3097580/asian-americans-trumpadministrations-attack-affirmative-action

Hero, R., Sidney, M., Clarke, S., Fraga, L. R., \& Erlichson, B. A. (2006). Multiethnic moments: The politics of urban education reform (Illustrated ed.). Temple University Press.

Hing, B. O. (1994). Making and remaking Asian America through immigration policy, 18501990 (1st ed.). Stanford University Press.

Ho by Ho v. San Francisco Unified School District, 965 F. Supp. 1316 (N.D. Cal. 1997). https://law.justia.com/cases/federal/district-courts/FSupp/965/1316/2138871/

Ho ex rel. Ho v. San Francisco Unified School District, 147 F.3d 854 (9th Cir. 1998).

Ho v. San Francisco Unified School District, 59 F.Supp. 2d 1021 (N.D.Cal. 1999).

Ho v. United States, (9th Cir. filed Dec. 14, 1998) (No. 98-7415).

Holding, R. (2012, January 18). William Orrick - U.S. district judge. SFGATE. https://www.sfgate.com/bayarea/article/William-Orrick-U-S-district-judge2595886.php

Hopwood v. Texas, 78 F. 3d 932 (1996). Johnson v. San Francisco Unified School District, 393 F. Supp. 1315 (N.D. Cal. 1971). https://law.justia.com/cases/federal/districtcourts/FSupp/339/1315/1460757/ Johnson v. San Francisco Unified School District, 500 F.2d 349 (9 $9^{\text {th }}$ Cir. 1974). https://casetext.com/case/johnson-v-san-franciscounified-sch-dist

Jones, T., \& Nichols, A. H. (Eds.). (2020, January). Hard truths (ED603265). ERIC. The Education Trust. https://files.eric.ed.gov/fulltext/ED603265.pdf

Kee, $\mathrm{H}$ (n.d.), [Picture from a typical Chinatown banquet with up to 700 people eating and talking politics, circa 1990s to 2000s.] [Photograph]. SF Hep B Free.

Kopp, Q. L. (2001). Oral history interview with Quentin L. Kopp [Interview by Donald B. Seney]. California State University, Sacramento, California State Archives; State Government Oral History Program.

Kuo, J. (1998). Excluded, segregated and forgotten: A historical view of the discrimination of Chinese Americans in public schools. Asian American Law Journal, 5(1), 181. https://doi.org/10.15779/Z385G39

Laird, H. (1988a, August 26). Schools chief raps busing. AsianWeek.

Laird, H. (1988b, August 5). Der raps schools chief over Asian administrators. AsianWeek.

Lau, D. (1993, March 12). CADC protests consent decree at school board meeting. AsianWeek.

Law.com. (n.d.). Orrick. Law.com. Retrieved Nov. 14, 2020, from https://www.law.com/americanlawyer/law-firm-profile/?id=227\&name=Orrick 
Lee, J. (2021). Asian Americans, affirmative action \& the rise in Anti-Asian hate Jennifer Lee. Daedelus, 150(2), 180-198. https://doi.org/10.1162/daed_a_01854

Lee, M. J., Collins, J. D., \& Harwood, S. A. (2020). If you aren't White, Asian or Indian, you aren't an engineer": Racial microaggressions in STEM education. STEM Education Journal, 7(48). https://doi.org/10.1186/s40594-020-00241-4

Levine, D. (2000). The Chinese American challenge to court-mandated quotas in San Francisco's public schools: Notes from a (partisan) participant-observer. Harvard Black Letter Law Journal, 16, 39-145.

Levine, D. (2003). Public school assignment methods after Grutter and Gratz: The view from San Francisco. Hastings Constitutional Law Quarterly, 30(4), 511. https://repository.uchastings.edu/cgi/viewcontent.cgi?article=1752\&context=hastings_ constitutional_law_quaterly

Lew, G. A. (1995). Perspectives on affirmative action and its impact on Asian Pacific Americans. Diane Pub Co.

Lim, G. (1994, August 19). Lawsuit over Chinese American HS enrollment: Class warfare by the Bay? AsianWeek. https://www.proquest.com/

Linsey, R. (1982, May 9). The new Asian immigrants. New York Times. https://www.nytimes.com/1982/05/09/magazine/the-new-asian-immigrants.html

Liu, C. M. (1998). Beyond Black and White: Chinese Americans challenge San Francisco's desegregation plan. Asian Law Journal, 5, 341. https://lawschoolmoodle.org/racism.org/articles/race/64-defining-racial-groups/asianamericans/8775-beyond-black-and-white

Lum, P. A. (1975). The Chinese Freedom Schools of San Francisco: A case study of the social limits of political system support (ED124646) (Unpublished doctoral dissertation). ERIC. https://eric.ed.gov/?id=ED124646

May, M. (2012, January 31). The fix-it guy / Henry Der's job is to rebuild bankrupt Emery school district. SFGATE. https://www.sfgate.com/education/article/The-fix-it-guyHenry-Der-s-job-is-to-rebuild-2852888.php

McGurn, W., \& Rothenberg, S. (1989, September 15). The invisible success story; Asian Americans and politics (p. 17). National Review.

Mercury News. (2013, September 11). Community anticipates Main Street Cupertino groundbreaking 15. Sept. The Mercury News. https://www.mercurynews.com/2013/09/11/community-anticipates-main-streetcupertino-groundbreaking-sept-15/

Mercury News. (2018, December 22). Amy Paayfen Chang 1964 - 2018. Legacy.Com. https://www.legacy.com/obituaries/mercurynews/obituary.aspx?n=amy-paayfenchang\&pid $=191047397 \&$ fhid $=2110$

Missouri v. Jenkins, 515 U.S. 70 (1995),

Nelson, E. S., Pitner, R., \& Pratt, C. D. (2017). Assessing the viability of race-neutral alternatives in law school admissions. Iowa Law Review, 102(5), 2187. https://ilr.law.uiowa.edu/print/volume-102-issue-5/assessing-the-viability-of-raceneutral-alternatives-in-law-school-admissions/

Nguyen, M. H., Chang, C. Y., \& Kim, V. (2020). Asian Americans, admissions, and college choice: An empirical test of claims of harm used in federal investigations. Educational Researcher, 49(8), 579-594. https://doi.org/10.3102/0013189X20933288

Okihiro, G. (2005). The Columbia guide to Asian American history (Columbia guides to American history and cultures) (Complete numbers starting with 1, 1st ed.). Columbia University Press.

Omi, M., \& Winant, H. (1994). Racial formation in the United States: From the 1960s to the 1990s (Critical social thought) (2nd ed.). Routledge. 
Order appointing special master, San Francisco Unified School District, (N.D. Cal. Sept. 23, 1998) (No. C-94-2419-WH).

Orfield, G., \& Glass, D. (1994, October). Asian students and multiethnic desegregation. The Harvard Project on school desegregation. https://civilrightsproject.ucla.edu/research/k12-education/integration-and-diversity/asian-students-and-multiethnicdesegregation/asian-students_orfield_glass.pdf

Orfield, Gary, Report on the Proposed Settlement, Ho v. San Francisco Unified School District, , 59 F.Supp. 2d 1021 (N.D.Cal. 1999).

Orrick, W. H., III. (2016, October 10). [Photograph]. Geni.Com. https://www.geni.com/photo/view/6000000048122552045?album_type=photos_of_m e\&photo_id=6000000048123899512

Orrick, W. H., Jr. (1989). William H. Orrick: A life in public service: California politics, the Kennedy administration, and the federal bench [Interview by Robert Van Nest in 1987 and 1988]. The Bancroft Library, University of California; Berkeley Oral History Center.

Orrick, W. H., Sr. (2016, October 10). [Photograph]. Geni.Com. https://www.geni.com/people/William-Orrick-Sr/6000000048122231398

Parker, W. (2000). The future of school desegregation. SSRN Electronic Journal, 1-92. https://doi.org/10.2139/ssrn.238717

Pepin, E., \& Watts, L. (2006) Harlem of the west: The San Francisco Fillmore jazz era. Chronicle Books.

Pew Center. (2019, December 31). Pew social trends chapter 1: Portrait of Asian Americans. pewsocialtrends.com. https://www.pewsocialtrends.org/2012/06/19/chapter-1-portraitof-asian-americans/

Platt, W. J., \& Harker, R. A. (1967, March). Improving racial balance in the San Francisco public schools. Summary report. Stanford Research Institute.

Quinn, R. (2020). Class action: Desegregation and diversity in San Francisco schools. University of Minnesota Press.

Research, Planning and Accountability Department. (2012, November 10). SFUSD enrollment 1967-2012F.

Richardson, J. (1999, December 5). The emperor inside the clothes. San Francisco Chronicle.

Robson, M., \& Riley, S. (2019). A Deleuzian rethinking of time in healthy lifestyle advice and change. Social \& Personality Psychology Compass, 13(4), e12448. https://doi.org/10.1111/spc3.12448

Rohrlich, M. (1998, July 19). Feeling isolated at the top, seeking roots. New York Times. https://www.nytimes.com/1998/07/19/style/feeling-isolated-at-the-top-seekingroots.html

San Francisco Board of Education. (2020, October 20). Agenda Oct 20, 2020 - Regular Meeting. San Francisco Unified https://go.boarddocs.com/ca/sfusd/Board.nsf/goto?open\&id=BSL8MK1EAB77

San Francisco Examiner Editorial Board. (1970, January 7). School plan friends, foes air their views. San Francisco Examiner.

San Francisco Examiner Editorial Board. (1986, November 11). Chinese Americans at the polls. San Francisco Examiner.

San Francisco Examiner Editorial Board. (1988, August 11). S.F. schools rethink ethnic mix. San Francisco Examiner.

San Francisco NAACP v. San Francisco Unified School District, 484 F. Supp. 657 (N.D. Cal. 1979). https://casetext.com/case/san-francisco-naacp-v-san-francisco-unified-sch

San Francisco NAACP v. San Francisco Unified School District, 576 F. Supp. 34 (N.D. Cal. 1983). https://law.justia.com/cases/federal/district-courts/FSupp/576/34/2593333/ 
San Francisco NAACP v. San Francisco Unified School, 59 F. Supp. 2d 1021 (N.D. Cal. 1999). https://law.justia.com/cases/federal/district-courts/FSupp2/59/1021/2408686/

Shioya, T. (1995, June 19) White student feels pride --and guilt -- profile Naomi Strom. San Francisco Chronicle, A8.

Sing Tao Staff, Sing Tao. (1994, May 27). 三藩市華裔家長反對設族裔上限的混合教育政 策，本來是有節有理. 學校應打開大門招生，不分種族，按客觀公平的原則取錄. Sing Tao Daily.

Stone, C. N., Henig, J. R., Jones, B. D., \& Pierannunzi, C. (2001). Building civic capacity: The politics of reforming urban schools. Studies in government and public policy. University Press of Kansas.

Students for Fair Admissions v. President \& Fellows of Harvard College, 397 F. Supp. 3d 126 (D. Mass. 2019) (No. 19-2005).

Students of Sociology of Asian America/ns, Fall 2019., \& Shaw, V. (2019). The Harvard syllabus: A guide to the affirmative action debate at Harvard. Department of Sociology, Harvard https://sociology.fas.harvard.edu/files/sociology/files/harvardsyllabus.pdf

University.

Superior Court of San Francisco. (2015). Judge Lillian K. Sing announces retirement after more than 30 years as a San Francisco jurist. SF Superior Court. https://www.sfsuperiorcourt.org/sites/default/files/pdfs/JudgeSing.pdf.

Takagi, D. Y. (1990). From discrimination to affirmative action: Facts in the Asian American admissions controversy. Social Problems, 37(4), 578-592. https://doi.org/10.2307/800583

Takagi, D. Y. (1993). The retreat from race: Asian-American admissions and racial politics. Rutgers University Press.

Takaki, R. (1998). Strangers from a different shore: A history of Asian Americans (Revised \& updated ed.). Little, Brown and Company.

Takaki, R. (2008). Different mirror: A history of multicultural America (1st ed.). Back Bay Books.

Thompson, V. (1978, October 5). Jack and Jill chapters: The top of the hill for Black professionals. Washington Post. https://www.washingtonpost.com/archive/local/

1978/10/05/jack-and-jill-chapters-the-top-of-the-hill-for-black-professionals/f40417e7-3e054a75-8dbc-8667b4d6dc36/

Torres, G. B. (2020). Affirmative action in higher education: Relevance for today's racial justice battlegrounds. Human Rights Magazine, 44(4). https://www.americanbar.org/groups/crsj/publications/human_rights_magazine_home/ black-to-the-future-part-ii/affirmative-action-in-higher-education--relevance-fortoday-s-ra/

Tucker, J., \& Knight, H. (2016, February 1). Living together, learning apart. San Francisco Chronicle. https://www.sfchronicle.com/schools-desegregationdistricts/\#:\%7E:text=But\%20in\%20San\%20Francisco\%2C\%20one,system\%20that $\% 2$ 0emphasizes\%20parental\%20choice.

U.S. Department of Justice., \& Durham, J. (2020, October 7). United States of America vs Yale University [Press release]. https://www.justice.gov/opa/pressrelease/file/1326306/download

US News and World Report. (2020). US news rankings - Best high schools in America. US News and World Report. https://www.usnews.com/education/best-highschools/california/districts/san-francisco-unified-school-district/lowell-high-school3259 
Walker, R. L. (2014). The living present as a materialist feminist temporality. Women: A Cultural Review, 25(1), 46-61. https://doi.org/10.1080/09574042.2014.901107

Walsh, D. (1989, July 20). Shifting programs may violate desegregation plan. San Francisco Examiner.

Walsh, J. (1993, November 7). S.F. schools at crossroads. San Francisco Examiner.

Wells, V. (2016, July 13). How do you feel about Jack and Jill. Madame Noire. https://madamenoire.com/706551/how-do-you-feel-about-jack-and-jill/

Wermund, B. (2018, October 14). GOP courts Asian-Americans with drive to end affirmative action. POLITICO. https://www.politico.com/story/2018/10/14/asian-americansaffirmative-action-898521

Wong, S. (1993, March). CADC president's remarks 35th annual banquet (pp. 3-4). Chinese American Democratic Club Fiery Dragon Newsletter.

Wong, S. (1994, January). 1993 annual report part II: Putting Chinese Americans first (p. 1). Chinese American Democratic Club Fiery Dragon Newsletter.

Wood, J. (1970, January 28). Alioto will aid busing opponents. San Francisco Examiner.

Wu, F. H. (1995). Neither Black nor White: Asian Americans and affirmative action. Boston College Third Waw Journal, 225. https://heinonline.org/HOL/LandingPage?handle=hein.journals/bctw15\&div=15\&id= \&page $=$

Wu, F. H. (2003). Yellow: Race in America beyond Black and White (Reprint ed.). Basic Books.

Yau, A. (2018, August 26). Amy's memorial - Part 2. lastingmemories. https://www.lastingmemories.com/memorial/amy-paayfen-chang?lifestory.

Yee, N. (1987, April 27). Letter to Diane Feinstein. Wu Yee Resource and Referral Center.

Zia, H. (2001). Asian American dreams: The emergence of an American people (1st ed.). Farrar, Straus \& Giroux.

\section{Interviews}

Personal interviews, recorded and transcribed.

$\begin{array}{ll}\text { David Campos } & \text { April 30, 2020 } \\ \text { Douglas Chan } & \text { November 1, 2019 } \\ \text { Michal Chan } & \text { April 28, 2020 } \\ \text { Lee Cheng } & \text { September 1, 2019 } \\ \text { Harrison Chow } & \text { March 16, 2020 } \\ \text { Harrison Chow } & \text { March 20, 2020 } \\ \text { Harrison Chow } & \text { October 22, 2020 } \\ \text { Peter Cohn } & \text { November 12, 2019 } \\ \text { Peter Cohn } & \text { May 1, 2020 } \\ \text { Henry Der } & \text { December 6, 2019 } \\ \text { Carol Kocivar } & \text { March 25, 2020 } \\ \text { Louis Hop Lee } & \text { March 20, 2020 } \\ \text { Tony Lee } & \text { March 27, 2020 } \\ \text { David Levine } & \text { March 10, 2020 } \\ \text { David Levine } & \text { July 29, 2020 } \\ \text { David Levine } & \text { October 27, 2020 } \\ \text { Hoover Liddell } & \text { October 23, 2020 } \\ \text { Henry Louie } & \text { October 28, 2019 } \\ \text { Elizabeth McGriff } & \text { June 27, 2020 } \\ \text { Ilona McGriff } & \text { May 23, 2020 }\end{array}$


Fang, T.

Victor Seeto September 19, 2019

Lillian Sing \& Julie Tang

(joint interview) February 18, 2020

Samson Wong January 4, 2020

Samson Wong February 12, 2020

\section{Notes on Contributor}

Ted Fang is a writer-author, and a pioneer in media and business. He was the first Asian American to serve as Editor and Publisher of a major metropolitan daily newspaper in the United States. Prior to that, he also ran the largest publications printing company in San Francisco and the largest non-daily newspaper in the country. Mr. Fang has a degree in Ethnic Studies from UC Berkeley and learned Chinese at Peking University. His community and philanthropic activities include co-founding the Hep B Free campaign and helping to develop the U.S. National Viral Hepatitis Action Plan to alleviate the greatest health disparity for Asians in America. ORCID ID\# 0000-0002-8982-203X 